\title{
Current State of Understanding of the Role of PACAP in the Hypothalamo-Hypophyseal Gonadotropin Functions of Mammals
}

\section{OPEN ACCESS}

Edited by:

Richard Ivell,

University of Nottingham,

United Kingdom

Reviewed by:

James M. Olcese

Florida State University, United States

Hubert Vaudry,

Université de Rouen, France

*Correspondence:

Ágnes Csák

csaki.agnes@med.semmelweis-univ.hu

Specialty section:

This article was submitted to

Reproduction,

a section of the journal

Frontiers in Endocrinology

Received: 21 October 2019

Accepted: 11 February 2020

Published: 06 March 2020

Citation:

Köves K, Szabó E, Kántor O,

Heinzlmann A, Szabó F and Csáki Á (2020) Current State of Understanding of the Role of PACAP in the

Hypothalamo-Hypophyseal

Gonadotropin Functions of Mammals.

Front. Endocrinol. 11:88.

doi: 10.3389/fendo.2020.00088

\section{Katalin Köves ${ }^{1}$, Enikö Szabó ${ }^{2}$, Orsolya Kántor ${ }^{3}$, Andrea Heinzlmann ${ }^{4}$, Flóra Szabó ${ }^{5}$ and Ágnes Csáki ${ }^{1 *}$}

'Department of Anatomy, Histology and Embryology, Faculty of Medicine, Semmelweis University, Budapest, Hungary, ${ }^{2}$ Department of Conservative Dentistry, Faculty of Dentistry, Semmelweis University, Budapest, Hungary, ${ }^{3}$ Department of Molecular Embryology, Medical Faculty, Institute of Anatomy and Cell Biology, University of Freiburg, Freiburg, Germany, ${ }^{4}$ Department of Anatomy and Histology, University of Veterinary Sciences, Budapest, Hungary, ${ }^{5}$ Department of Pediatrics, Virginia Commonwealth University, Richmond, VA, United States

PACAP was discovered 30 years ago in Dr. Akira Arimura's laboratory. In the past three decades since then, it has become evident that this peptide plays numerous crucial roles in mammalian organisms. The most important functions of PACAP are the following: 1. neurotransmitter, 2. neuromodulator, 3. hypophysiotropic hormone, 4. neuroprotector. This paper reviews the accumulated data regarding the distribution of PACAP and its receptors in the mammalian hypothalamus and pituitary gland, the role of PACAP in the gonadotropin hormone secretion of females and males. The review also summarizes the interaction between PACAP, $\mathrm{GnRH}$, and sex steroids as well as hypothalamic peptides including kisspeptin. The possible role of PACAP in reproductive functions through the biological clock is also discussed. Finally, the significance of PACAP in the hypothalamo-hypophysial system is considered and the facts missing, that would help better understand the function of PACAP in this system, are also highlighted.

Keywords: PACAP, reproduction, mammals, male, female

\section{INTRODUCTION}

Pituitary adenylate cyclase activating polypeptide (PACAP) was discovered 30 years ago in Dr. Akira Arimura's laboratory in an effort to find the still undefined follicle stimulating hormone-releasing factor (FRF). It was discovered that a fraction of ovine hypothalamus was able to stimulate adenylate cyclase (AC) in rat primary anterior pituitary cell cultures (1). The peptide isolated from this tissue was then characterized. It is composed of 38 amino acids. The N-terminal sequence shows $68 \%$ homology with vasoactive intestinal polypeptide (VIP); however, its AC stimulating activity is at least 1,000 times greater than that of VIP. It was named PACAP38. PACAP belongs to the VIP/glucagon/secretin family. Its effect was tested on superfused pituitary cells and it demonstrated the ability to enhance the release of growth hormone $(\mathrm{GH})$, prolactin (PRL), corticotropin (ACTH) and luteinizing hormone (LH). From fractions of hypothalamic tissues, a shorter form composed of 27 amino acids was also isolated, and it was named PACAP27. PACAP27 showed similar AC stimulating activity as PACAP38 (2). Further studies showed that PACAP stimulated AC in a multitude of other tissues. Its official name is now adenylate cyclase activating polypeptide (ADCYAP). It was also 
demonstrated that PACAP could stimulate other intracellular signal transduction mechanisms such as the phospholipase$\mathrm{C} /$ protein kinase $\mathrm{C}$ (PLC/PKC) cascade (3). The human PACAP gene is located on chromosome 18p11.32 and encodes a 176amino acid preproprotein, which comprises a 24-amino acid signal peptide (4). The cDNA encoding precursor of PACAP38 was successfully cloned from an ovine hypothalamic cDNA library by Kimura et al. (5).

The N-terminal domain of PACAP is responsible for the biological activity. Removal of the first amino acid $\left(\mathrm{His}^{1}\right)$ of this domain reduced the potency and affinity of the peptide to its receptors. The removal of further amino acids decreased its affinity to the receptors to even greater degree. Finally, removal of the first five amino acids (PACAP6-38) resulted in an antagonist of PACAP (6).

PACAP is the most ancient and one of the most conserved member of the secretin superfamily (7). This peptide is found from invertebrates to humans. PACAP was demonstrated in various non-mammalian vertebrates such as different species of fish (8-11), frogs (12-17) and birds $(18,19)$. PACAP was able to stimulate AC in frog anterior pituitary cells $(13,14,20)$.

Several important papers have reviewed the distribution of PACAP and its receptors, and the most important roles including the significance of PACAP in the reproductive functions (21-24). In the present paper we have focused on the role of PACAP in the mammalian reproductive system.

\section{DISTRIBUTION OF PACAP IN THE HYPOTHALAMUS}

In mammals the distribution of PACAP in the hypothalamus was demonstrated by immunohistochemistry (IHC) (25-30),

Abbreviations: AC, adenylate cyclase; $\mathrm{ACN}$, anterior commissural nucleus; ACTH, adrenocorticotropic hormone; ADCYAP, adenylate cyclase activating polypeptide; ADNP, activity dependent neuroprotective protein; $\alpha M S H$, $\alpha$-melanocyte-stimulating hormone; ARC, arcuate nucleus; AVP, arginine vasopressin; $\mathrm{BBB}$, blood-brain barrier; c-AMP, cyclic adenosine-monophosphate; CIBA, cell immunoblot assay; $\mathrm{CRH}$, corticotropin hormone-releasing hormone; DHT, dihydrotestosterone; Dy, dynorphin; EGFP, enhanced green fluorescence protein; EIA, enzyme immunoassay; ER $\alpha$, estrogen receptor $\alpha$; ER $\beta$, estrogen receptor $\beta$; FG, FluoroGold; FRF, follicle-stimulating hormone-releasing factor; FS, folliculostellate cell; FSH, follicle-stimulating hormone; GFP, green fluorescence protein; GH, growth hormone; GnRH, gonadotropin hormonereleasing hormone; GRP, gastrin releasing peptide; HPLC, high pressure liquid chromatography; IHC, immunohistochemistry; ia, intraarterial; icv, intracerebroventricular; in, intranasal; ip, intraperitoneal; $i v$, intravenous; ISH, in situ hybridization; KNDy, kisspeptin/neurokinin B/dynorphin; KP, kisspeptin; LH, luteinizing hormone; $\mathrm{MBH}$, medial basal hypothalamus; $\mathrm{ME}$, median eminence; NKB, neurokinin B; NPY, neuropeptide Y; NSE, neuron specific enolase; ODN, oligodeoxynucleotide; OT, oxytocin; PACAP, pituitary adenylate cyclase activating polypeptide; PCR, polymerase chain reaction; Pe, periventricular region; Pf, perifornical region; RHPA, reverse hemolytic plaque assay; $\mathrm{PHI}$, peptide histidine isoleucine; PKC, protein kinase C; PLC, phospholipase-C; POA, preoptic area; POMC, pro-opiomelanocortin; PRL, prolactin; PRP, PACAP related peptide; PVN, paraventricular nucleus; mPVN, magnocellular portion of PVN; pPVN, parvocellular portion of PVN; RIA, radioimmunoassay; RT-PCR, reverse transcription-polymerase chain reaction; SCN, suprachiasmatic nucleus; S-EIA, sandwich enzyme immunoassay; SON, supraoptic nucleus; T4, tetraiodothyronine; TSH, thyroid stimulating hormone; VAChT, vesicular acethycholine transporter; VIP, vasoactive intestinal polypeptide; VMN, ventromedial nucleus. radioimmunoassay (RIA) (31), sandwich enzyme immunoassay (S-EIA) (32) and in situ hybridization (ISH) $(30,33,34)$.

Mapping of PACAP required the development of antibodies. The initial antibodies were polyclonal rabbit antibodies. The most potent antibodies were characterized by enzyme immunoassay (EIA) (25) and RIA (31). PACAP in mammals shows the same amino acid sequence $(5,35-37)$ therefore, antibody against ovine PACAP was able to stain not only in ovine tissues $(25,38)$, but in many other mammalian species such as rats (26), humans, monkey (27), hamsters, guinea-pigs, ferrets, cats, and pigs (39).

In the hypothalamus IHC revealed PACAP neuronal cell bodies in the supraoptic (SON), paraventricular (PVN), anterior commissural nuclei (ACN), periventricular $(\mathrm{Pe})$ and perifornical regions (Pf), well-defined immunoreactive fiber network in the median eminence (ME) and suprachiasmatic nucleus (SCN) $(25,26,40)$. The staining was more prominent in colchicine pretreated rats. PACAP in similar localization was also demonstrated by Kivipelto et al. (28) and Tamada et al. (29). In the ME of intact rats PACAP fibers were mainly found in the internal zone; however, 3 weeks after hypophysectomy the fiber staining appeared in the external zone as well (26), from where PACAP might be released into the pituitary portal circulation. Dow et al. (41) demonstrated that PACAP was present in the hypophysial portal blood of both male and female rats and the amount of PACAP (measured by RIA) was significantly greater than in the peripheral blood. Reversed phase high performance liquid chromatography (HPLC) revealed that the major form in portal blood was PACAP38. The localization of PACAP hypophyseotropic neurons, which send fibers to the portal capillaries, was demonstrated with FuoroGold (FG) tracer injected intraperitoneally (ip). From the intraperitoneal space, FG can enter the blood stream and the central nervous system through the ME and the posterior pituitary where the blood-brain barrier (BBB) is missing (42). In control animals FG, spreading in a retrograde manner, appeared in several hypothalamic regions [Pe, arcuate nucleus (ARC), SON and both parvo- (pPVN) and magnocellular portions of PVN (mPVN)]. In pituitary stalk-sectioned rats FG entered the hypothalamus only through the capillary loops of the ME. The stalk section prevented the tracer from entering the hypothalamus through the posterior pituitary. In this model labeling was found in the parvocellular nuclei and the ventral portion of the mPVN. The SON was completely empty. Double labeling revealed that the FG labeled neurons, located in the periventricular area and the ventral portion of $\mathrm{mPVN}$, also showed PACAP immunoreactivity (43). Based on these results the authors concluded that these neurons were hypophyseotropic. Former electron microscopic investigations showed that hypophyseotropic PACAP neurons terminated around the pituitary portal capillaries (29). These neurons may release PACAP into the portal blood.

Hannibal et al. $(30,33)$ using RIA, IHC and ISH techniques also mapped PACAP in the hypothalamus. RIA revealed that levels of PACAP38 were about 60 times higher than PACAP27 and 10 times higher than the level of PACAP related peptide (PRP). With the use of monoclonal antibodies PACAP and PRPimmunoreactive neuronal perikarya were observed in the medial portion of the pPVN in colchicine pretreated rats. Some PACAP 
cell bodies were found in the mPVN and the dorsal aspect of the SON. PACAP mRNA containing cells were observed in moderate numbers in the vascular organ of the lamina terminalis, the $\mathrm{PVN}$, the medial mammillary nuclei (MM) and the ventromedial nucleus (VMN).

Moore et al. (34) examined PACAP mRNA expression in the PVN and anterior pituitary of rats using ISH and reverse transcription-polymerase chain reaction (RT-PCR) technique. It was found that PACAP mRNA levels varied significantly during the estrous cycle. PACAP mRNA levels in the PVN declined on the morning of diestrus and started to increase on the morning of proestrus. Highest levels were found $3 \mathrm{~h}$ before the proestrous gonadotropin surge then PACAP mRNA level declined again.

A few years ago an impressive method was used to map PACAP in the central nervous system of mice. "Transgenic mouse line that harbors, in its genome, a bacterial artificial chromosome containing an enhanced green fluorescent protein (EGFP) expression cassette inserted upstream of the PACAP ATG translation initiation codon" was generated (44). PACAP in the hypothalamus was mainly observed in the PVN, VMN and MM. No green fluorescent protein (GFP) expression was seen in the SON. Figure 1 compares the data, obtained by different methods, concerning the distribution of PACAP protein and PACAP mRNA. It seems that the best correlation is found between mouse EGFP-PACAP (44) and rat PACAP mRNA (30).

There are several lines of evidence that PACAP in the rat hypothalamus colocalizes with some other peptides. Using double labeling immunohistochemistry, Dürr et al. (45) found that PACAP immunoreactivity was present in approximately $20 \%$ of pro-opiomelanocortin (POMC) neurons in the ventrolateral part of ARC. These neurons also showed $\alpha$-melanocyte-stimulating hormone ( $\alpha$-MSH) immunoreactivity. PACAP immunoreactivity was also colocalized with the vesicular acetylcholine transporter (VAChT) in ARC POMC neurons. Vereczki et al. (47) demonstrated that PACAP and VIP immunoreactive cells partially overlapped each other's region in the PVN and SON. Interestingly, in neither cats nor rats do PACAP and VIP immunoreactivities colocalize in the same cells. In spite of the high sequence homology of PACAP and VIP, the two peptides are synthesized in different subpopulations of hypothalamic neurons; however, partial colocalization of PACAP and oxytocin (OT) in the hypothalamic magnocellular neurons of colchicine treated and pituitary stalk sectioned rats was demonstrated. In rats, colchicine treatment and pituitary stalk section enhanced the amount of PACAP and VIP and allowed successful immunostaining in the hypothalamus. PACAP and VIP immunoreactive materials were also stored in different fibers of the posterior pituitary. PACAP fibers formed a dense plexus at the periphery of the posterior lobe, in the vicinity of the intermediate lobe; however, VIP fibers were evenly distributed mainly in the center of the posterior lobe $(46,48)$.

\section{PACAP IN THE ANTERIOR PITUITARY}

The occurrence of PACAP was observed in both lobes of the pituitary gland. RIA revealed that PACAP levels were much higher in the posterior than in the anterior lobe of the pituitary gland, $270 \mathrm{pmol}$ vs. $3.8 \mathrm{pmol} / \mathrm{g}$ wet tissue (31). High levels of PACAP in the posterior pituitary are explained by the fact that PACAP immunoreactive magnocellular neurons send their axons to this part of the gland $(25,26)$. The number of hypophysiotropic PACAP neurons, those release PACAP to the portal blood, is limited compared to those sending fibers to the posterior pituitary. Most studies using RIA were performed in male rats. There is no available data using RIA to measure levels of PACAP in the anterior pituitary of female rats having various stage of estrous cycle. RT-PCR technique demonstrated that the levels of PACAP in the anterior lobe increased during proestrus (49). In this stage of the ovarian cycle PACAP immunoreactive cells were observed in the anterior pituitary of female rats using IHC. Double labeling showed that PACAP immunoreactivity was present in LH and follicle stimulating hormone (FSH) cells (50). Moore et al. (34) examined PACAP mRNA levels not only in the hypothalamus, but also in the anterior pituitary of female rats. PACAP mRNA levels also varied on the afternoon of proestrus. There was a moderate decrease at the time of the gonadotropin surge (in the afternoon of proestrus between 16 and $20 \mathrm{~h}$ ) and a significant increase later in the evening. Expression of mRNA encoding follistatin increased significantly following the rise in pituitary PACAP mRNA at the termination of the secondary surge in FSH $\beta$. ISH clearly showed that PACAP expression in the anterior pituitary of male rats was negligible similarly to that of diestrous rats and transiently enhanced in the proestrous stage of female rats. Significantly higher levels were found late evening $(20 \mathrm{~h})$ with decrease in the numbers of PACAP expressing cells $2 \mathrm{~h}$ later $(22 \mathrm{~h})$ (51). IHC was able to reveal PACAP immunoreactivity only in LH and FSH cells, folliculostellate cells (FS) were negative (50). However, RT-PCR analysis of enriched populations of FS did reveal the presence of PACAP in these cells as well (52). The level of PACAP in individual FS cells has to be very low, not enough for immunostaining.

\section{PACAP RECEPTORS}

PACAP shows high sequence homology with VIP therefore binding sites have been characterized on the basis of their relative affinities for PACAP and VIP. Soon after the discovery of PACAP, its receptors were also identified (53-56). The members of the International Union of Basic and Clinical Pharmacology Committee on Receptor Nomenclature and Drug Classification (NC-IUPHAR) subcommittee on receptors for VIP and PACAP agreed on a common nomenclature $(57,58)$. According to their agreement there are three G-protein coupled receptors: PAC1 (specific for PACAP), VPAC1 and VPAC2 (both of which bind PACAP and VIP with equal affinity). The C-terminal end of PACAP binds to its receptors (59). The receptor is a protein composed of 495 amino acids with seven transmembrane domains (60). Dejda et al. (61) identified regions within the extracellular N-terminal domain of PAC1 which were the major binding sites for PACAP. Three peptide derivates containing a photoreactive p-bensoyl-phenilalanine residue were developed. These photoreactive peptides linked to three fragments of 
A

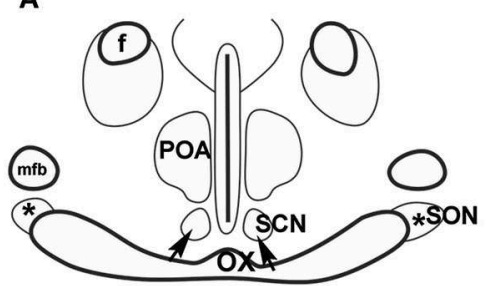

IA $7,7 \mathrm{~mm}$

B

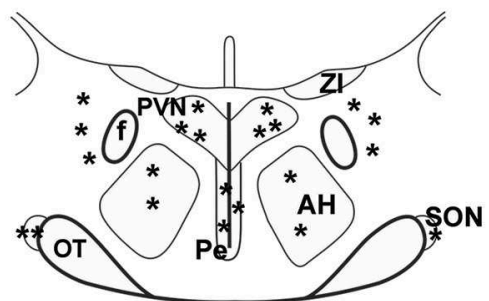

IA 7,2mm

C

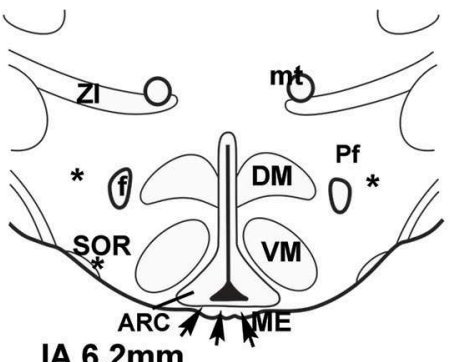

IA $6,2 \mathrm{~mm}$

D

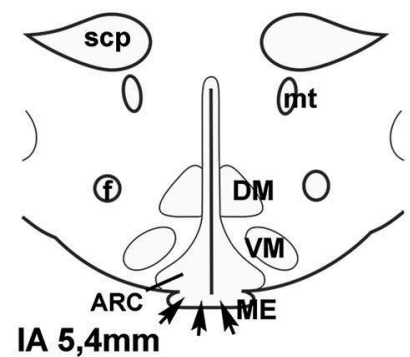

E

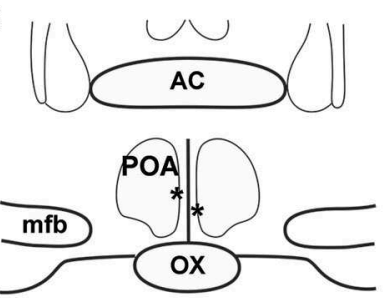

$8,7 \mathrm{~mm}$

F

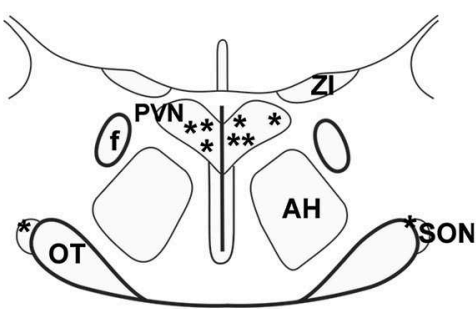

7,2mm

G

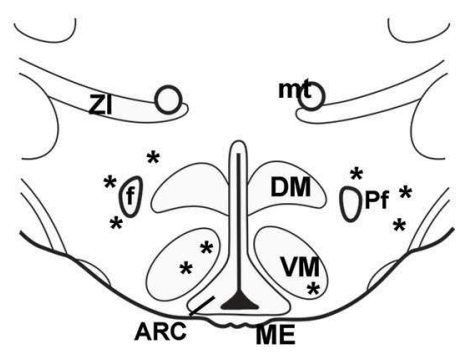

$6,2 \mathrm{~mm}$

H

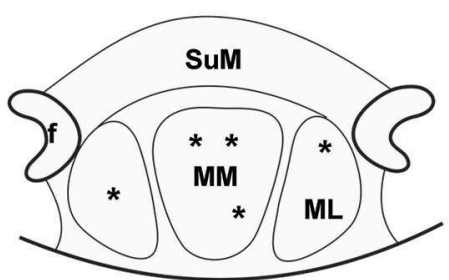

4,4mm
I
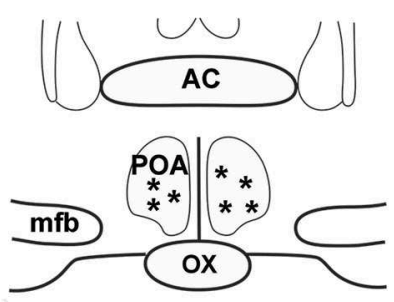

$3,82 \mathrm{~mm}$

J

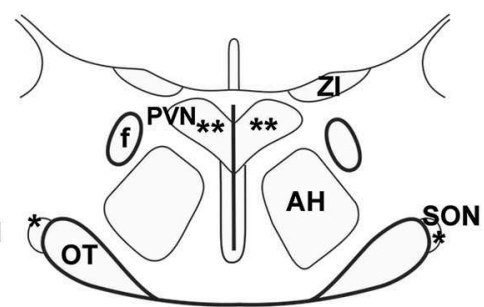

$3,22 \mathrm{~mm}$

K

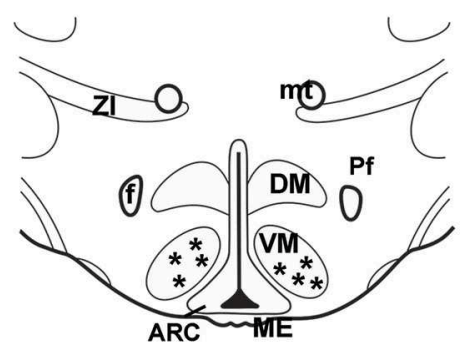

$2,10 \mathrm{~mm}$

L

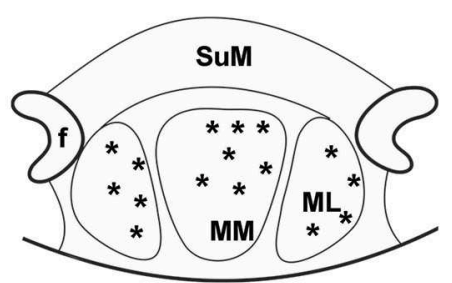

$0,72 \mathrm{~mm}$

FIGURE 1 | (A-H) Distribution of PACAP-immunoreactive cells and fibers and PACAP mRNA- expressing cells in frontal sections of the rat hypothalamus according to Paxinos and Watson's stereotaxic coordinates. (I-L) Distribution of PACAP expressing neurons in PACAP-EGFP transgenic mouse hypothalamus according to Franklin and Paxinos' Mouse Brain in stereotaxic Coordinates. (A-D) shows PACAP immunoreactive elements in rats. Data were obtained by Köves et al. (26), Kivipelto et al. (28), and Tamada et al. (29). (E-H) shows PACAP mRNA expressing cells in rats. Data were obtained by Hannibal et al. (33); Moore and et al. (34) and Dürr et al. (45). (I-L) shows EGFP-PACAP in transgenic mice (44). Asterisks indicate cell bodies, arrows indicate fibers. AC, anterior commissure; $A H$, anterior hypothalamus; $f$, fornix; $M E$, median eminence; $m f b$, medial forebrain bundle; $M L$, medial mammillary nucleus, lateral part, $M M$, medial mammillary nucleus; $m t$, mammillothalamic tract, OT, optic tract; OX, optic chiasm; Pe, periventricular nucleus; Pf, perifornical nucleus; POA, preoptic area; $P V N$, paraventricular nucleus; SCN, suprachiasmatic nucleus; scp, superior cerebellar peduncle; SON, supraoptic nucleus; SOR, retrochiasmatic portion of SON; SuM, supramammillary nucleus; ZI, zona incerta. Reproduced and modified from Köves et al. (46). Permission to reuse was obtained from Springer Nature. Permission \# 4762591108219.

extracellular domains: Ser (62) —Met (63) segment, Ser (64)—Glu (65) dipeptide, and Ser (66)-Met (67).

More detailed analysis using RT-PCR technique with PAC1specific primers revealed splice variants of PAC1: PAC1s (short form and very short form), PAC1hop1, PAC1hop2, PAC1hip, PAC1hiphop1, PAC1hiphop2, PAC13a and PAC1TM4. Except for the short form (also called null form) the splice variants have inserts in the third intracellular loop. The hip cassette 
contains 28 amino acids, hop1 28, and hop2 27 amino acids. Stimulation of short and hop1 variants potently increase AC and PLC (3). The very short form lacks 57 amino acids in the first extracellular loop and displays decreased affinity to PACAP27 and PACAP38, but its affinity toward VIP remains the same (68). Blechman and Levkowitz (69) summarized all data concerning the splice variants of PAC1 receptor. An alternative splicing of Nterminal part of the receptor was also found. Alternative splicing alters ligand binding properties and induces different outcomes of the receptor function. A 21-amino acid deletion in the $\mathrm{N}$ terminal extracellular domain resulted in a new splice variant of PAC1 receptor. This domain modulates receptor selectivity and controls the relative potencies of PACAP27 and PACAP38 in PLC stimulation (70).

\section{PACAP Receptors in the Hypothalamus}

In the hypothalamus, PACAP dose dependently stimulates both AC and PLC activities. RT-PCR revealed that in the hypothalamus the major receptor splice variants were PAC1s and PAC1hop2 (71, 72). Joo et al. (73) investigated the distribution of PAC1, VPAC1 and VPAC2 receptors using IHC. In the hypothalamus the most intensive PAC1 labeling was found in $\mathrm{ARC}$, anterior and intermediate $\mathrm{Pe}$, medial preoptic area (POA) and SCN. Occurrence of PAC1 receptors overlaps the major part of the location of gonadotropin hormone-releasing hormone $(\mathrm{GnRH})$ neurons and the termination of the retinohypothalamic pathway in SCN. ISH (74) revealed that PAC1 gene expression showed similarly widespread distribution in the hypothalamus. Autoradiography (75) demonstrated binding sites for PACAP which were not shared with VIP. The most dense and consistent labeling was found in SON and ARC, and moderate presence in SCN, Pe and the lateral hypothalamus by both methods. Additionally, ISH showed labeling in PVN, ventromedial (VMN) and dorsomedial nuclei (DMN). A physiological role of PACAP receptors in the latter two nuclei was also demonstrated (76). Moderate PAC1 receptor mRNA expression was also found in SON and PVN of rat by Nomura et al. (77) using ISH. On the basis of the above-mentioned data it seems that the distribution pattern of PACAP receptors, described by various researchers, depends on the applied methods.

What kind of cells exhibits PAC1 expression or immunoreactivity? The cells exhibiting PAC1 immunoreactivity in the hypothalamus are not fully characterized. Rat brain astrocytes in cell culture exhibit PACAP binding $(78,79)$, which is associated with proliferation of astrocytes (80). Some research groups (81-83) identified a specific PACAP receptor on astrocytes besides VIP type2 receptor. It was also shown that the VIP neuronal survival effect was partially mediated via PAC hop2 splice variants present in astrocytes (81).

It is also unclear what the source of PACAP is for PACAP binding sites of astrocytes. Do neurons also express PAC1 receptors? Shioda et al. (84) examined SON and they found PACAP innervation and PAC1 expression on arginine vasopressin (AVP) but not on OT neurons. PACAP was present in noradrenergic fibers from medulla. PAC1 was found on arcuate POMC cells. About 50\% of POMC cells express this receptor $(45,85)$. Later PAC1 and VPAC2 receptor mRNA was also found on neuropeptide Y (NPY) neurons in the ARC (86). It is possible that PACAP receptors are also present on $\mathrm{GnRH}$ neurons. Olcese et al. (87) were able to show PACAP receptors on immortalized GnRH neuronal cell lines, but not on processed hypothalamic slides. Nakamachi et al. (88) reported that activity dependent neuroprotective protein (ADNP) in mouse brain colocalized with $\mathrm{PAC1}$ and in the septum and hippocampus ADNP positive cells also exhibited neuron specific enolase (NSE) immunoreactivity. The results obtained by the various methods on the localization of $\mathrm{PAC1}$ receptor in the hypothalamus are summarized in Figure 2.

\section{PACAP Receptors in the Anterior Pituitary}

Soon after the discovery of PACAP, specific binding sites were reported on rat and human pituitary cell membranes $(54,89,90)$. ISH and Northern blot analysis revealed a high expression of PAC1 in the anterior and intermediate lobes of the pituitary; however, a very low expression was found in the posterior pituitary $(3,91)$. Vígh et al. (92) demonstrated that biotinylated PACAP38 could bind to each cell type in anterior pituitary cell culture. About $90 \%$ of S-100-positive cells bound biotinylatedPACAP38. A considerable number of GH, PRL and ACTH, and only a few LH, FSH and thyroid stimulating hormone (TSH) producing cells bound PACAP.

All PACAP receptor types including PAC1, VPAC1 and VPAC2 were found in normal rat anterior pituitary tissue and aT3-1 gonadotrope cell lines $(93,94)$, although PACls and PAClhop1 variants were the dominant forms. Stimulation of short and hop1 variants potently increases AC and PLC as well as intracellular [Ca2+] levels (95).

\section{ROLE OF PACAP IN THE GONADOTROPIC HORMONE SECRETION OF FEMALES}

\section{The Effect of PACAP on the GnRH-LH Axis Hypothalamic Level}

At the advent of PACAP research, it seemed that PACAP was a hypophysiotropic factor which stimulated AC in rat anterior pituitary cell cultures (1). In vivo experiments were carried out in rats (96-99), mice $(100,101)$, and sheep (102). As mentioned before, the release of PACAP into rat portal circulation was demonstrated by Dow et al. (41).

Studying the effects of PACAP administration and investigating the lack of PACAP or its specific receptors (PAC1) in certain tissues provide good insight into the role of PACAP in the reproductive functions. The effect of PACAP administration on the gonadotropic hormone secretion varies by dose and route of administration, the studied species, sex, as well as on stages of estrous cycle in females.

\section{Intravenous (iv) administration}

There are only some experiments where PACAP38 was administered iv to female rats before the critical period of proestrous stage of estrous cycle, when the central nervous system prepares itself for the GnRH release. Its effect was examined on plasma LH levels and ovulation. $10 \mu \mathrm{g}$ iv PACAP38 had no effect on plasma LH level and did not interfere with ovulation $(96,97)$. 


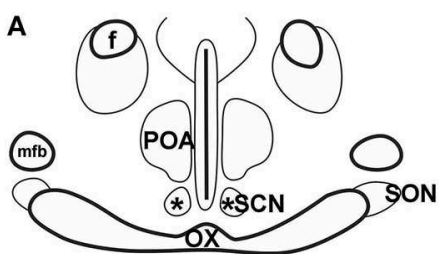

IA $7,7 \mathrm{~mm}$

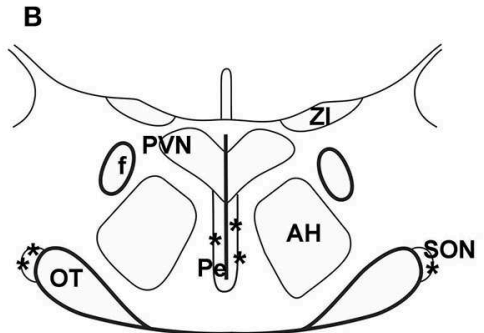

IA $7,2 \mathrm{~mm}$

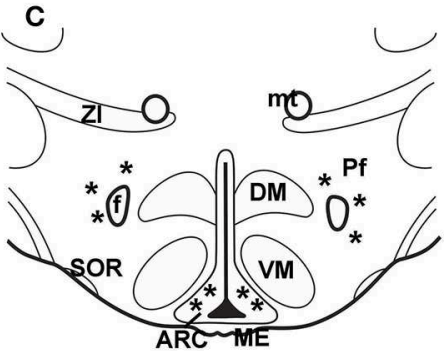

IA $6,2 \mathrm{~mm}$

D

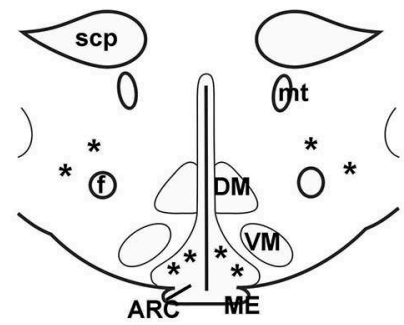

IA $5, \mathbf{4 m m}$

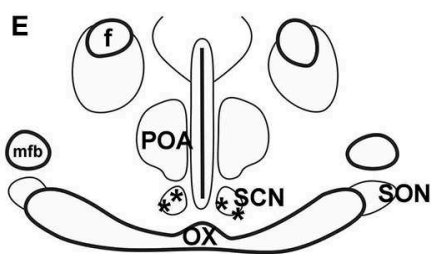

$7,7 \mathrm{~mm}$

F

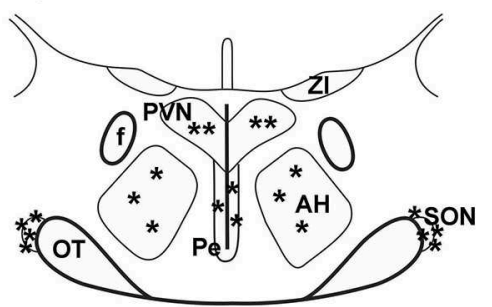

$7,2 \mathrm{~mm}$

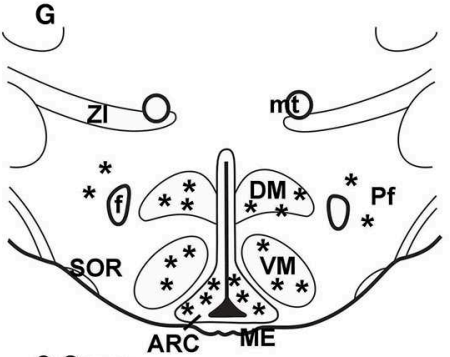

$6,2 \mathrm{~mm}$

H

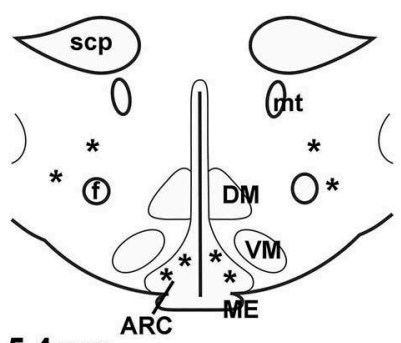

$5,4 \mathrm{~mm}$

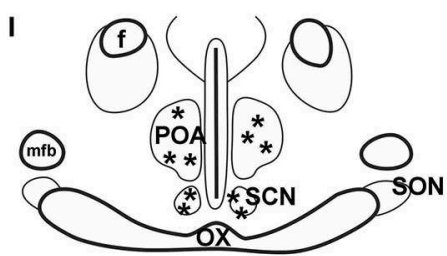

$7,7 \mathrm{~mm}$

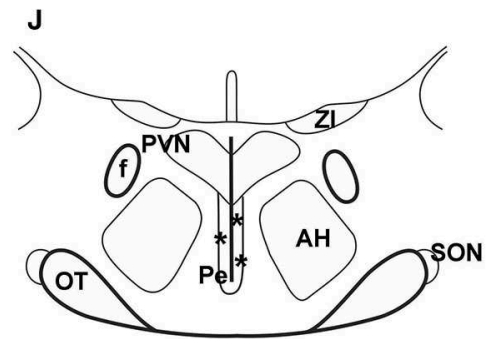

$7,2 \mathrm{~mm}$

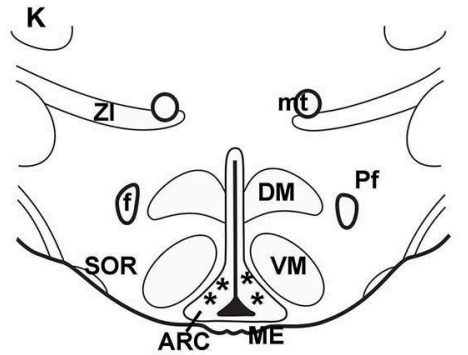

$6,2 \mathrm{~mm}$

L

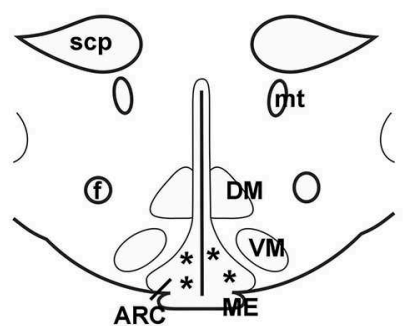

$5,4 \mathrm{~mm}$

FIGURE 2 | Distribution of PAC1 receptor in frontal sections of the hypothalamus according to Paxinos and Watson's stereotaxic coordinates. (A-D) shows data obtained by autoradiography (75). (E-H) shows distribution of PAC1 mRNA. Data were obtained by ISH (74, 77). (I-L) shows distribution of PAC1 receptor immunoreactivity using $\mathrm{IHC}$ (73). Asterisks indicate the place of PACAP binding, or where PAC1 mRNA was expressed or where PAC1 immunoreactivity was detected. $A H$, anterior hypothalamus; $f$, fornix; $M E$, median eminence; $m f b$, medial forebrain bundle; $m t$, mammillothalamic tract; $O T$, optic tract; $O X$, optic chiasm; $P$, periventricular nucleus; Pf, perifornical nucleus; POA, preoptic area; PVN, paraventricular nucleus; SCN, suprachiasmatic nucleus; scp, superior cerebellar peduncle; SON, supraoptic nucleus; SOR, retrochiasmatic portion of SON; ZI, zona incerta. Reproduced and modified from Köves et al. (46). Permission to reuse was obtained from Springer Nature. Permission \# 4762591108219.

\section{Intracerebroventricular (icv) administration}

In the above-mentioned model $10 \mu \mathrm{g}$ of PACAP38 administered $i c v$ before the critical period of the proestrous stage prevented the proestrous LH surge and the expected ovulation on the next morning $(96,103)$; however, PACAP27 in a same model enhanced plasma LH level and did not influence ovulation (97). The inhibitory effect of PACAP was not a direct action on $\mathrm{GnRH}$ neurons; rather it was mainly mediated through corticotropinreleasing hormone $(\mathrm{CRH})$ and endogenous opioids $(97,98)$. It is possible that $\mathrm{CRH}$ directly acts on $\mathrm{GnRH}$ neurons because MacLusky et al. (104) have shown interaction between CRH and $\mathrm{GnRH}$ neurons in rats. It was also shown that the inhibitory effect of $\mathrm{CRH}$ on $\mathrm{LH}$ secretion is mediated through endogenous opioids (105). Sawangjaroen and Curlewis (102) used ovariectomized 
ewes for their experiments. PACAP38 was effective when it was administered $i c v$ and it depressed the frequency and amplitude of LH pulses. The same research group demonstrated that the inhibitory effect of PACAP was mediated through the medial basal hypothalamus of sheep (106). We have to consider that the migration of $\mathrm{GnRH}$ neurons caudally differs among mammals. In rats, GnRH neurons, forming a loose network, are located in the septo-preoptico-anterior hypothalamic area, and the neuronal cell bodies do not reach the medial basal hypothalamus. Only their axons project to the ME $(107,108)$; however, in humans, similarly to most mammals (including sheep, monkeys, bat, cat, horse, rabbit, guinea pig), GnRH neurons are present in the tuberoinfundibular region as well [reviewed by (109)].

\section{Intranasal (in) administration}

The effect of many drugs has been studied by the intranasal (in) application as well. When PACAP is given iv it can cross the blood-brain-barrier (BBB) to a modest degree by way of a saturable transport system (110). It is possible that $10 \mu \mathrm{g}$ PACAP given $i v$ was not enough to prevent ovulation $(96,97)$. Nonaka et al. (111) demonstrated that PACAP given in was effective in improving memory in a very low dose $(0.01 \mu \mathrm{g})$. In our laboratory, $10 \mu \mathrm{g}$ of PACAP38 (similar dose which was effective $i c v$ ) was sprayed through the left nostril onto the olfactory region of rats before the critical period of proestrous stage. PACAP prevented ovulation in half of the animals. When ovulation was blocked plasma LH remained at basal levels (99).

\section{The effect of PACAP on the onset of puberty}

When PACAP was administered to neonatal female rats on the 2 nd day of life in a subcutaneous injection ( $1 \mu \mathrm{g} / \mathrm{animal})$, it delayed puberty and decreased the number of expelled ova at the first ovulation (112). The intensity of GnRH immunostaining in the septo-preoptico-infundibular system measured in 30-day-old rats was decreased, although there was no difference in the weight of the anterior pituitaries. The pituitary LH content also showed a decrease in PACAP treated rats. PACAP antiserum had a reverse effect on GnRH immunoreactivity. Image analysis supported the light microscopic observations of $\mathrm{GnRH}$ immunostaining (112). When PACAP was injected on the 7 th day of life, it had no effect on the onset of puberty (46). It seems that neonatal PACAP administration delayed the onset of puberty through the influence of the GnRH neuronal system. It is well-known that the GnRH neurons in mammals derive from the olfactory region $(113,114)$. Likely PACAP administration on the 2nd day of life does not inhibit, but slows down the migration of the $\mathrm{GnRH}$ neurons. But how it is realized, has not been clarified.

Choi et al. (115) examined the role of PACAP and PAC1 in the onset of puberty in female rats. They found that PACAP and PAC1hop1 mRNA in the hypothalamus decreased during the first proestrous day. Disruption of PAC1 synthesis by icv administration of a PAC1 antisence oligodeoxynucleotide (ODN) in the late juvenile period considerably decreased $\mathrm{GnRH}$ levels in the hypothalamus, GnRH receptor mRNA and LH $\beta$ in the anterior pituitary. These alterations induced delay of vaginal opening and first ovulation. It is probable that, in the lack of PAC1 synthesis, PACAP is not effective. In adult rats PACAP mRNA levels rise just before the critical period of the proestrous stage then it decreases during the critical period (34). Without PAC1 receptor in this period, elevated PACAP cannot exert its effect. Because the development of $\mathrm{GnRH}$ system is completed by the late juvenile period, it is logical that the onset of puberty is only delayed, not missed.

\section{The effect of hypophysectomy on hypothalamic PACAP}

Köves et al. (26) demonstrated, that 3 weeks after hypophysectomy, PACAP immunoreactive fibers appeared in the external zone of the ME, although they were not seen in intact or colchicine treated rats. It is possible that under normal physiological conditions PACAP is continuously released into the portal circulation, but this baseline level of the peptide in the ME is insufficient for immunostaining. However, significant decreases in PACAP mRNA and radioimmunoassayable PACAP contents were observed in the hypothalamus 1-2 weeks after hypophysectomy. These decreased levels were restored by administration of GH, PRL, tetraiodothyronine (T4), corticosterone, and testosterone (62).

\section{Pituitary Level}

Dow et al. (41) clearly showed that hypothalamic born PACAP was released into the pituitary portal circulation. Later it became evident that PACAP mRNA was present in the anterior pituitary $(51,116)$ and PACAP is synthetized in the gonadotropes $(50)$. The amount of pituitary born PACAP is very low when measured by S-EIA (117), much lower than that of LH (118). Cell immunoblot assay (CIBA) demonstrated release of PACAP from anterior pituitary cells into the culture medium (117). The number of PACAP releasing cells was very low in male and diestrous female rats, and tremendously enhanced in the cultures taken from the pituitaries of proestrous rats late in the evening (20 h) (119). These data clearly show that PACAP is transiently expressed in the anterior pituitary and the number of PACAP releasing cells "in adult rat anterior pituitary cell culture depends on the gender, stage of the estrous cycle in female animals, and on the time of day when the animals were sacrificed" (46). The low amount of PACAP in the anterior pituitary confirms the previous hypothesis that pituitary born PACAP is an auto- and paracrine regulator as it was demonstrated by Radleff-Schlimme et al. (62). Usually two gonadotrope cell lines (L $\beta$-T2 and $\alpha \mathrm{T} 3$ 1) derived from transgenic female mice are used to study the effect of drugs on gonadotropin hormone secretion. $\alpha$ T3-1 cells express the $\alpha$-subunit gene even though they do not express the $\beta$-subunit and cannot synthesize LH or FSH, but also express GnRH receptor. Radleff-Schlimme et al. (116) showed that in $\alpha$ T3-1 cell cultures PACAP was released into the medium. This observation well correlates with results showing that PACAP is present in gonadotropes (50) and these cells release PACAP into the cell culture medium (117).

\section{The effect of PACAP on gonadotropic hormone release}

Soon after the discovery of PACAP Culler and Paschall (120), Hart et al. (121) demonstrated a weak stimulatory effect of PACAP on LH, FSH and $\alpha$-subunit release in primary pituitary cell cultures. It was also shown that PACAP and GnRH interacted 
synergistically to stimulate LH release (120). Szabó et al. (119) demonstrated that PACAP could stimulate LH release in pituitary cell cultures derived from proestrous rats. It was visualized by CIBA. This technique is able to show the LH release from individual cells. It was found that "the responsiveness of LH cells to PACAP depends on the gender, on the time of day when the animals were sacrificed and in females on the stage of estrous cycle". LH cells kept the information received in vivo. Those cells taken from the proestrous animals in the morning (10h) were most sensitive to PACAP stimulus.

Kanasaki et al. (122-124) used L $\beta$-T2 cell lines to investigate the role of PACAP on $\mathrm{LH} \beta$ subunit release. It was found that PACAP (similarly to $\mathrm{GnRH}$ ) administered to the cell culture in high frequency pulses, increased LH $\beta$ subunit secretion and in low frequency pulses it increased FSH $\beta$ subunit secretion. They hypothesize that, under physiological conditions, PACAP contributes to the dynamic control of gonadotropin hormone secretion. In another experiment, PACAP dose-dependently increased cAMP accumulation and increased the basal levels of the $\alpha$-subunit through the PAC1 receptors and had a synergistic effect on GnRH in $\alpha$ T3-1 cells (125).

\section{The effect of PACAP on pituitary gonadotropin gene expression}

Tsujii et al. $(126,127)$ used anterior pituitary cells from adult intact and orchidectomized rats. In a perifusion system, pulsatile PACAP stimulated $\alpha$-subunit and LH $\beta$ mRNA levels but did not affect FSH $\beta$ mRNA. By contrast, continuous PACAP increased $\alpha$-subunit mRNA levels, but suppressed FSH $\beta$ mRNA without affecting LH $\beta$ mRNA. With the use of $\alpha \mathrm{T} 3-1$ cell line it was found that the effect of PACAP on the $\alpha$-subunit expression was mediated by PAC1 receptor and in part by the cAMP/PKA pathway (128). In other experiments in rat gonadotropes and folliculostellate cells PACAP stimulated follistatin gene expression. PACAP or continuous GnRH downregulated FSH $\beta$ mRNA. This action required follistatin $(63,129)$.

Another research group compared the effect of PACAP and $\mathrm{GnRH}$ on gonadotropin gene expression in static pituitary culture and in L $\beta$-T2 perifused cells (122). In their experiment, high-frequency PACAP pulse preferentially enhanced LH $\beta$ gene, whereas low-frequency PACAP pulses specifically enhanced FSH $\beta$ gene. This pattern imitated the effect of GnRH pulses. Follistatin gene expression showed similar changes to that of LH $\beta$ gene expression; it was increased following high-frequency pulses of either GnRH or PACAP. Low-frequency PACAP pulses enhanced PAC1 expression, whereas high-frequency pulses enhanced $\mathrm{GnRH}$ receptor expression.

The above-mentioned results clearly show that the rate of gonadotropin hormone secretion is under a very complex regulation, and the results depend on the circumstances [reviewed by (130)]. In in vivo experiments, we have to take into account many other known and unknown factors which may influence the effect of PACAP. The factors may derive from the hypothalamus, from the pituitary itself or from the periphery. Because the cell cultures used in the studies were not taken from different stages of the estrous cycle, we cannot claim
TABLE 1 | Effect of PACAP38 on the LH level in vivo.

\begin{tabular}{lccc}
\hline $\begin{array}{l}\text { Route of } \\
\text { administration }\end{array}$ & Dose of PACAP38 & LH & \\
\hline & & Female & $(131)^{\star}$ \\
iv & $10 \mu \mathrm{g} / 250 \mathrm{~g}$ rat & - & \\
icv & $10 \mu \mathrm{g} / 250 \mathrm{~g}$ rat & $\downarrow$ & $(97)^{\star}$ \\
icv & $10 \mu \mathrm{g} / 250 \mathrm{~g}$ rat & $\downarrow$ & $(99)^{\star}$ \\
in & $10 \mu \mathrm{g} / 250 \mathrm{~g}$ rat & $\downarrow$ & $(102)^{\star \star}$ \\
icv & $45 \mu \mathrm{g} / \mathrm{ewe}$ & $\downarrow$ & $(157)$ \\
& & Male & \\
ia & $10 \mu \mathrm{g} / 250 \mathrm{~g}$ rat & $\uparrow$ & \\
& $30 \mu \mathrm{g} / 250 \mathrm{~g}$ rat & $\uparrow \uparrow$ & \\
& $100 \mu \mathrm{g} / 250 \mathrm{~g}$ rat & $\uparrow \uparrow \uparrow$ & $(132)$ \\
icv & $0.8 \mu \mathrm{g} / 250 \mathrm{~g}$ rat & - & \\
& $8 \mu \mathrm{g} / 250 \mathrm{~g}$ rat & $\uparrow$ & $\uparrow$ \\
& $32 \mu \mathrm{g} / 250 \mathrm{~g}$ rat & $\uparrow \uparrow$ & $\uparrow$ \\
iv & $10 \times 10 \mu \mathrm{g}$ rat & $\uparrow$ & \\
icv & $0.4 \mu \mathrm{g} / 100 \mathrm{~g}$ rat & $\uparrow$ & \\
\hline
\end{tabular}

${ }^{*}$ Given before the critical period of proestrous stage.

${ }^{* *}$ Given to ovariectomized ewes.

${ }^{\star * \star}$ Given in hourly injection.

la, intraarterial; icv, intracerebroventricular; in, intranasal; iv intravenous.

$\downarrow$ decrease, $\uparrow$ moderate increase, $\uparrow \uparrow$ high increase, $\uparrow \uparrow \uparrow$ very high increase.

that the findings completely mirror the changes in the female pituitary gland.

Table 1 summarizes the data concerning the effect of PACAP38 on LH levels in living animals. Table 2 shows data on the effect of PACAP38 and GnRH on gonadotropin hormone release and gene expression obtained in various cell cultures. It seems that in vitro PACAP is basically stimulatory on gonadotropic hormone secretion. As it was mentioned above, our data, obtained by CIBA and pituitary cell cultures, clearly showed that the stimulatory or inhibitory role of PACAP on LH release depends "on the gender, stage of the estrous cycle in female animals, and on the time of day when the animals were sacrificed" (119).

\section{Knock Out of PACAP or Its Receptor on Gonadotropin Hormone Secretion}

Several research groups generated PAC1 or PACAP knock-out mice $(100,133-135)$. The mortality of PAC1 null mice was extremely high, $60 \%$ in a month after birth. The animals showed serious metabolic disorders. The surviving females showed reduced fertility, but not the males. Normal LH, FSH and PRL staining was observed in their pituitaries (133). Another research group generated both PACAP and PAC1 null mice. Mortality of both PACAP and PAC1 null mice was very high in the first month of life. However, females, that survived beyond this period, exhibited onset of puberty in time. They showed normal estrous cycle. The seminal plug was also normal after pairing. The most strinking abnormality was that only $13 \%$ of fertilized eggs were implanted on day 6.5 after mating. Because PRL and progesterone levels were reduced in these animals the authors suggested that the impaired implantation was due to low PRL and 
TABLE 2 | Effect of PACAP38 and GnRH on the gonadotropic hormone level and gene expression in cell cultures.

\begin{tabular}{|c|c|c|c|c|c|}
\hline \multirow{2}{*}{$\begin{array}{l}\text { Type of Cell } \\
\text { Cultures } \\
\begin{array}{l}\text { Perifused cell } \\
\text { culture }\end{array}\end{array}$} & \multicolumn{4}{|c|}{ Examined Parameters } & \\
\hline & $\alpha$-subunit & $\mathrm{LH}$ & FSH & & \\
\hline CPACAP & $\uparrow$ & - & $\uparrow$ & & $(126,127)$ \\
\hline pPACAP & $\uparrow$ & $\uparrow$ & - & & $(63,129)$ \\
\hline Primary cell culture & $\begin{array}{c}\alpha \text {-subunit } \\
\text { mRNA }\end{array}$ & $\begin{array}{c}\alpha \text {-subunit } \\
\text { protein }\end{array}$ & & & $(128)$ \\
\hline PACAP & $\uparrow$ & & & & \\
\hline GnRH & $\uparrow \uparrow$ & $\uparrow \uparrow$ & & & \\
\hline$\alpha \mathrm{T} 3-1$ cell line & & & & & (128) \\
\hline PACAP & $\uparrow$ & $\uparrow$ & & & \\
\hline $\mathrm{GnRH}$ & $\uparrow$ & $\uparrow$ & & & \\
\hline Primary cell culture & $\alpha$-subunit & $\mathrm{LH} \beta$ & $\mathrm{FSH} \beta$ & PAC1 & (122) \\
\hline \multicolumn{6}{|c|}{ promoter activity } \\
\hline CPACAP & $\uparrow$ & & & & \\
\hline$c G n R H$ & $\uparrow$ & $\begin{array}{r}\uparrow \\
\text { mRNA }\end{array}$ & $\uparrow$ & & \\
\hline CPACAP & $\uparrow$ & $\uparrow$ & $\uparrow$ & & \\
\hline $\begin{array}{l}\text { CGnRH + PACAP } \\
\text { perifused } L \beta-T 2\end{array}$ & $\uparrow$ & $\uparrow$ & $\uparrow$ & & \\
\hline pPACAP high $f$ & & $\uparrow \uparrow$ & $\uparrow$ & $\uparrow$ & \\
\hline pPACAP low $f$ & & $\uparrow$ & $\uparrow \uparrow$ & $\uparrow \uparrow$ & \\
\hline $\mathrm{GnRH}$ & & & & $\uparrow$ & \\
\hline
\end{tabular}

P, pulsatile; c, continuous; $f$, frequency.

$\uparrow$ moderate increase, $\uparrow \uparrow$ high increase.

progesterone levels (101). Similarly, low birth rates were found by Shintani et al. (135), but they found reduced mating and maternal behavior as well.

\section{The Effect of PACAP on PRL Secretion Hypothalamic Level}

PRL is one of the anterior pituitary hormones. The most prominent role of PRL is to stimulate milk secretion. Later it became evident that PRL was synthetized in many structures other than pituitary. PRL was found in the central nervous system, the immune system, the uterus and in the mammary gland itself and it is accepted that PRL has a multifunctional role [reviewed by (136)].

The effect of PACAP on PRL release is well-established. Miyata et al. (1) found that in superfused cell cultures PACAP stimulated PRL release. Nagy et al. (137) used a special model to examine the effect of PACAP on PRL release. Rat pups were separated from their mother, suckling was suspended. During this refractory period, iv injection of PACAP was able to stimulate PRL release in the mothers. However, in sheep PACAP administered icv stimulated dopamine release from the tuberoinfundibular dopaminergic neurons and this effect was associated with a suppression of PRL level in the peripheral blood (138). Tohei et al. (139) observed a similar effect after icv administration of PACAP to lactating rats exposed to suckling stimuli. PACAP38 decreased PRL secretion and increased the activity of thyrosin hydroxydase (TH) in ME of the pituitary stalk. On the other hand, icv injection of PACAP38 did not affect PRL secretion and $\mathrm{TH}$ activity in lactating rats, who had their pups taken away, removing the suckling stimuli. Contrary to this, Nagy et al. (137) found that $i v$ administration was stimulatory in these same circumstances. It means that PACAP directly stimulated PRL release from the lactotropes.

\section{Pituitary Level}

PACAP stimulated PRL release from superfused pituitary cells at a very low dose $\left(10^{-10} \mathrm{M}\right)$ (1). It has been also shown that lactotropes bind biotinylated PACAP38 with high affinity (92). Later, in PRL producing cells three PAC1 variants were detected using RT-PCR method (140). The question arises: what is the source of PACAP for these receptors? Does it originate from the hypothalamus or from the pituitary itself? It seems that PACAP may originate from both sources. Jarry et al. (141) found contrasting in vivo and in vitro effects of PACAP on PRL release. In the in vitro experiments, they used reverse hemolytic plaque assay (RHPA). In this model PRL was inhibited by PACAP. In in vivo experiments, they have used medial basal hypothalamus lesioned rats. The lesion destroyed tuberoinfundibular dopaminergic neurons and plasma PRL levels rose. I $v$ administered PACAP further stimulated PRL release. Another research group used a monolayer pituitary cell culture. In this model PACAP inhibited PRL release; however, in aggregated cell cultures or in pituitary fragments, PACAP was stimulatory. This means that a paracrine cell to cell communication is mandatory for the action of PACAP on PRL release. This communicating factor may be interleukin-6 (IL6) which was also stimulated by PACAP in both models (142). PACAP also induced PRL release using AtT-20 and GH3 cell lines (143). Oride et al. (23) summarized the data concerning the role of PACAP in the hypothalamic-pituitary system. They concluded that PACAP alone has a relatively weak simulatory effect on PRL gene expression in lactotropes and PACAP and TRH have a synergistic effect in this regard.

\section{PRL and PACAP in Milk}

Both PRL and PACAP are present in the milk. The level of PRL in milk is similar to the level found in the general circulation (144). Recently it was shown that dopamine agonists reduce not only milk yield through PRL inhibition, but also mammary epithelial cell activity, survival, and proliferation (145). PACAP was first demonstrated in human milk by Börzsei et al. (123). No significant differences were found in plasma PACAP level of women of different ages or hormone cycles. However, PACAP levels significantly increased in the second and third trimesters of pregnancy and during lactation (64). In milk whey the content of PACAP was 5-20-fold higher than in plasma, and the highest concentration was in colostrum. PACAP content is stable until the tenth month of lactation then it rises again (65). PACAP was also found in the plasma and milk of other mammals such as cow, goat and sheep (146). The source of PACAP, present in the milk, may originate from plasma or from autonomic and sensory nerve endings. PACAP has been shown to be present 
in nerve fibers, which innervate the smooth muscles of vessels, and in lactiferous ducts and fibers surrounding the alveoli. It was suggested that PACAP immunoreactive sensory fibers might transmit the suckling stimulus to the central nervous system (147). PACAP may also have an effect on mammary epithelium because PAC1 was demonstrated in this tissue using IHC (65). It is not known what the exact function of PACAP in milk is. Tamás et al. (148) hypothesized that "1. PACAP may be essential for the growth and development of newborn; 2. PACAP may be required for the development of the immune system and immunological microenvironment of the gastrointestinal tract; 3. PACAP could be important in the growth and function of the mammary gland."

\section{PACAP in Plasma}

PACAP is present in plasma. It was also demonstrated that plasma PACAP38 level increased during the second and the third trimester (64). Lactation moderately enhanced PACAP concentration (149). Kanasaki et al. (123) investigated plasma PACAP levels in human subjects. They found lower PACAP concentration in the second trimester of pregnancy and in several pathological conditions such as premature ovarian failure and idiopathic hypogonadotropic hypogonadism than in normal menstruating women. There is no clear evidence for the source of PACAP in plasma. We exclude the possibility that PACAP may originate from the anterior pituitary. Low PACAP concentration here is only enough for auto- and paracrine actions. Likely magnocellular PACAP neurons sending fibers to the posterior pituitary release a sufficient amount of PACAP into the general circulation $(25,26,47)$. PACAP could also originate from sensory nerve endings. Helyes et al. (150) found 2-fold higher PACAP levels in the blood after systematic stimulation of capsaicin-sensitive sensory nerves than in control animals. The most likely option is that PACAP originates from the placenta because PACAP immunoreactive fibers innervate vessels in the uteroplacental unit in humans (151). PACAP38 and PAC1 mRNA has been demonstrated in the placenta as well as immunoreactive stromal and decidual cells in humans and rats (152-155).

\section{THE ROLE OF PACAP IN THE GONADOTROPIN HORMONE SECRETION OF MALES}

At the beginning of PACAP research several research groups investigated the effect of PACAP in adult male rats in vivo. They used different routes of administration ( $i v, i c v$ and intraarterial [ia]). I $v$ administration of PACAP38 (10 $\mu \mathrm{g} / 100 \mathrm{~g} \mathrm{bw})$ decreased plasma LH levels (156), while its antagonist, PACAP6-38 elevated it. When PACAP38 was repeatedly administered as an iv bolus injection $(10 \times 10 \mu \mathrm{g})$, LH concentration was enhanced. Parallel with LH elevation, PACAP mRNA increased seven times in the anterior pituitary. It means that PACAP regulated its own expression (116). The authors supposed that the source of PACAP was the gonadotropes where PACAP exerted an autocrine effect. In another in vivo experiment icv administration of PACAP (0.4 $\mu \mathrm{g} / 100 \mathrm{~g}$ bw) enhanced LH levels while PACAP6-38 in a same dose decreased it (132). Osuga et al. (157) observed elevations of plasma LH after both ia and icv administration of PACAP38 (see above Table $\mathbf{1}$ ).

Ample experiments were carried out in in vitro models (126128). In monolayer anterior pituitary cell cultures from 7-weekold orchidectomized rats, PACAP attenuated GnRH stimulated $\mathrm{LH}$ secretion. When the cells were stimulated by $\mathrm{GnRH}$ in a pulsatile manner, continuous presence of PACAP in the culture further enhanced LH, FSH and the $\alpha$-subunit secretory episodes. This suggests that there is a synergistic effect between the two peptides (126). Later the same research group examined the effect of pulsatile administration of PACAP and found that "pulsatile PACAP stimulated $\alpha$-subunit and LH $\beta$ mRNA level but did not affect FSH $\beta$ mRNA. In contrast, continuous PACAP increased $\alpha$-subunit mRNA level, but suppressed FSH $\beta$ mRNA without affecting LH $\beta$ mRNA" (127). With the use of a perifused pituitary system PACAP (10 nM) was applied continuously. This treatment induced a rapid and transient release of gonadotropins from pituitary cells of both intact and orchidectomized 7-weekold rats. However, hourly pulsatile PACAP administration in a same dose induced episodic release of LH, FSH and $\alpha$-subunit, but frequency of these epsiodes gradually decreased. PACAP was a slightly more effective stimulator of $\mathrm{LH}$ release by pituitary cells deriving from castrated than from intact rats (127). It was also shown that PACAP stimulated follistatin gene expression in both gonadotropes and folliculostellate cells, and follistatin was required for PACAP to downregulate FSH- $\beta$ mRNA (129). Kanasaki et al. (122) found a striking difference between the effect of continuous and pulsatile administration of $\mathrm{GnRH}$ and PACAP on gonadotropic hormone secretion using L $\beta$-T2 cell line. The frequency of administration also influenced the effect of the two peptides. High-frequency PACAP pulses enhanced better LH $\beta$ gene expression than low frequency pulses and lowfrequency pulses enhanced better FSH $\beta$ gene expression than high-frequency pulses. The pattern of the effect of PACAP was similar to that of $\mathrm{GnRH}$.

Winters et al. (63) demonstrated that PACAP was able to stimulate $\alpha$-subunit expression and LH secretion and repress FSH synthesis in fetal male rat pituitary glands as well. Moore et al. $(158,159)$ revealed a reciprocal relationship between PVN PACAP and FSH $\beta$ gene expression in maturing rats. They observed that PACAP and follistatin levels decreased at birth and, as a consequence of it, FSH and the GnRH receptor levels increased. The onset of puberty is also characterized by the increase of FSH synthesis. Later the above-mentioned research group (160) created a transgenic mouse model in which pituitary PACAP was overexpressed. The overexpression was proven by IHC, Western blot, and ELISA analyses. Follistatin, $\mathrm{GnRH}$ receptor, and gonadotropin subunit mRNAs were also measured in the pituitary of male transgenic and wild-type mice of various ages using real-time PCR. FSH, LH, and testosterone levels appeared suppressed. In PACAP transgenic mice, in which gonadotropin subunit and GnRH receptor mRNA levels were reduced and the pituitary follistatin expression was increased, the onset of puberty was delayed. After orchidectomy, the testicular negative feedback of pituitary gonadotropin expression remained intact when it was examined in young adult animals (at age 70 days) (160). 


\section{INTERACTIONS BETWEEN PACAP, GNRH, AND SEX STEROIDS}

Lariviere et al. (161) demonstrated that in L $\beta$-T2 gonadotrope cell line PACAP38 treatment effectively increased intracellular cAMP while GnRH treatment was only mildly effective. In contrast, GnRH very potently enhanced inositol phospholipid turnover and PACAP had a very weak effect. They further investigated the mechanism of the cross-talk between the two peptides $(66,162)$. It was previously shown that PACAP38 stimulated cAMP via PAC1 receptors (163). Lariviere et al. (162) revealed the molecular mechanism of the cross-talk between PACAP and GnRH in the gonadotropes. They observed that GnRH inhibited the functional coupling of PACAP to the cAMP pathway via novel protein kinase-C (PKC) isoforms. They also demonstrated that $\mathrm{GnRH}$-activated PKC phosphorylated PAC1-R. Grafer et al. (164) found that GnRH stimulated PACAP gene expression in pituitary gonadotropes via multiple signaling pathways acting on CRE/AP-1 sites in the proximal gene promoter.

Ample evidence indicates that there is an interaction not only between PACAP and GnRH, but between these neuropeptides and peripheral sex steroids. It is well-known that ovarian steroids modulate LH secretion. Ortmann et al. (165) pretreated adult female pituitary cell cultures with estradiol, progesterone or both, then added GnRH or PACAP and analyzed the media for $\mathrm{LH}$ and CAMP production. Estradiol alone was able to enhance basal LH and cAMP levels, progesterone enhanced only LH, not cAMP. GnRH and PACAP stimuli further enhanced the steroid induced LH release. In another experiment in male rat anterior pituitary cell cultures GnRH treatment enhanced PACAP mRNA expression, dihydrotestosterone (DHT) or progesterone further enhanced this increase; however, DHT or progesterone alone had no effect on PACAP mRNA. On the contrary, estradiol alone depressed PACAP gene expression but did not alter the effect of GnRH on it. Expression of PACAP receptor mRNA was decreased by GnRH treatment, and minimally increased by DHT treatment, but was not altered by the addition of estradiol or progesterone. DHT and GnRH together blunted PACAP receptor gene expression (166). Grafer and Halvorson (167) confirmed the regulatory role of androgens in the function of PACAP. They showed that androgens stimulated rat PACAP promoter-reporter activity in the $\mathrm{L} \beta-\mathrm{T} 2$ mouse gonadotrope cell line.

A reciprocal interaction between PACAP and ovarian steroids in female rats was also demonstrated in the ovarietomized and sex steroid replacement model. PACAP and PAC1 mRNA expression was enhanced in the medial basal hypothalamus $(\mathrm{MBH})$ and PAC1 mRNA in POA as well upon treatment with progesterone or progesterone + estradiol (168). Németh et al. (169) published data about the effect of sex steroid deficiency on PACAP levels in the central nervous system. Gonadectomy temporarily decreased PACAP38 levels in many regions including the hypothalamus and the pituitary gland of both male and female rats. By 23 weeks post gonadectomy PACAP 38 levels were restored and actually continued to increase in the pituitary, surpassing concentrations of those seen in controls by the fourth month after gonadectomy.
The above-mentioned data suggest that there is a regulatory feed-back mechanism between the gonads and the hypothalamohypophyseal system. Interestingly, GnRH neurons do not express progesterone, androgen and $\alpha$-estrogen receptors. Ha et al. (168) suggested that the effect of progesterone on $\mathrm{GnRH}$ neurons may be mediated by PACAP neurons. The authors injected PAC1 ODN into the $3 \mathrm{rd}$ ventricle. This treatment depressed the progesterone induced enhancement of GnRH mRNA expression. We have to consider that there is no evidence that PACAP neurons exhibit progesterone receptors.

\section{INTERACTION BETWEEN PACAP AND OTHER HYPOTHALAMIC PEPTIDES}

Based on documented data in the literature, LH secretion seems to depend on the balance of the amount of GnRH and PACAP. Before the critical period of the proestrous stage, PACAP mRNA in the hypothalamic PVN is enhanced, followed by a decline during the critical period (34). Parallel to this, a large amount of $\mathrm{GnRH}$ is released into the portal circulation overwhelming PACAP and inducing LH surge. As GnRH release into the pituitary declines, local pituitary PACAP levels start to rise, now overwhelming GnRH and resulting in cessation of LH release from the anterior pituitary late in the afternoon (46).

PACAP38 regulates GnRH gene expression. Li et al. (156) investigated the effect of $i c v$ and $i v$ administered PACAP38 and its antagonist, PACAP6-38 on $\mathrm{GnRH}$ and somatostatin gene expression in the hypothalamus of male rats. Icv administration of PACAP induced increases of both $\mathrm{GnRH}$ and somatostatin gene expression. PACAP6-38 and iv administration of PACAP had an opposite effect. In female rats PACAP applied icv or in inhibited the proestrous GnRH release. This inhibitory effect may be mediated by the PVN (46), where a majority of $\mathrm{CRH}$ neurons are located (170). PACAP increases the hybridization signal of CRH in the PVN (132). The morphological basis of this observation is that $\mathrm{CRH}$ fibers establish synaptic contact with GnRH neurons in rats (104) and are found in close juxtaposition with GnRH neurons in the human infundibulum and $\mathrm{ME}$ (171). In rats PACAP fibers innervate the paraventricular CRH neurons (172). These observations strongly suggest that PACAP receptors are present on $\mathrm{CRH}$ neurons. In concordance with this morphological observation is the finding that $\mathrm{CRH}$ antagonist applied icv partially prevented the blocking effect of PACAP38 on ovulation (98).

There may be interactions between PACAP and endogenous opioids as well. This hypothesis well correlates with the observation that POMC neurons exhibit PAC1 and VPAC2 receptors in the ARC (45). The inhibitory effect of PACAP on ovulation can be prevented by ip administration of naloxone, a general opioid antagonist (98).

About two decades ago it was recognized that kisspeptin (KP) played an important role in the regulation of gonadotropic hormone secretion. In sheep, dynorphin (Dy), neurokinin B $(\mathrm{NKB})$ and $\mathrm{KP}$ were co-expressed in some ARC neurons. These cells were named kisspeptin/neurokinin B/dynorphin (KNDy) neurons (173). 
KNDy neurons were also observed in mammals other than sheep $(174,175)$. Ramaswamy et al. (176) demonstrated close interaction between the KP neurons located in the ARC and $\mathrm{GnRH}$ neurons in male rhesus monkey using confocal microscopy. KNDy neurons modulate GnRH pulsatile release into the pituitary portal vessels through Kiss1R and subsequent $\mathrm{LH}$ release into the circulation. These are the neurons, not $\mathrm{GnRH}$ ones, that are the target of ovarian steroids because KNDy neurons exhibit $\operatorname{ER} \alpha(177,178)$. Researchers have come to the consensus that these neurons are what mediate estrogen negative feedback on gonadotropin secretion (179). This cell group is called the $\mathrm{GnRH}$ pulse generator. $\mathrm{ER} \alpha$ is also expressed by KP neurons located in the POA. These neurons are the place of positive estrogen feedback which is responsible for the GnRH and LH surge (177). ER $\beta$, another estrogen receptor was discovered by Kuiper et al. (180) and a few years later its presence was demonstrated on GnRH cells using ISH, 125I-estrogen binding (181) and IHC (182, 183). Soon after the discovery of KP it became evident that this peptide plays an important role in reproductive functions. Mutation in the KP receptor (KISS1R /GPR54) leads to hypogonadotropic hypogonadism and infertility in humans (184). KP neurons contain not only $\mathrm{ER} \alpha$ but progesterone receptors as well (185).

With the use of L $\beta$-T2 it was recently demonstrated that KP10 and PACAP stimulated the expression of gonadotropin subunits, and their expression was further increased when KP10 and PACAP were administered together. KP10 increased PAC1 expression. KP neurons may be targets for PACAP in the hypothalamus (186). In a recent study PACAP neurons located in the premammillary nucleus were found to establish direct contact with KP neurons residing in ARC and preoptic Pe. "Targeted deletion of PACAP from the premammillary nucleus through stereotaxic virally mediated cre- injection or genetic cross to LepR-i-cre mice with PACAPfl/fl mice led to delayed puberty onset and impaired reproductive function in female, but not male, mice" (187).

In 2019, Tumurbaatar et al. (188) used immortalized female rat hypothalamic cell lines containing $\mathrm{KP}$ expressing neurons from anteroventral Pe (mHypoA-50) or the ARC (mHypo A55). In both models PACAP enhanced the expression of Kiss1, $\mathrm{CRH}$ and neurotensin genes. Its effect was prevented by a protein kinase inhibitor. PACAP was expressed in both cell models and its expression was increased by estradiol.

\section{PACAP IN THE RETINOHYPOTHALAMIC PATHWAY AND ITS ROLE IN THE CIRCADIAN CLOCK}

Under normal environmental illumination the LH and FSH plasma hormone levels show cyclic, circadian and circhoral fluctuations. If the illumination is constant, ovulation is interrupted and in rats continuous estrus is found in the vaginal smear. This phenomenon is explained by the "Scharrer hypothesis" (189), which states that photic stimuli from the eye are conducted not only to the main visual centers, but also to some hypothalamic neurons and then to neuroendocrine effector cells. He called this the photoneuroendocrine system. The anatomical basis of this system is the retinohypothalamic tract $(190,191)$. The retinohypothalamic tract consists of axons of a distinct population of ganglion cells that contain melanopsin and are responsible for non-image-forming photosensation and transmit signals to the brain (192). The main neurotransmitter of the retinohypothalamic tract is the glutamate. The presence of PACAP was demonstrated in this pathway $(103,193)$ and found to colocalizes with glutamate (194). PACAP, similarly to glutamate, has a light-like effect on circadian rhythms (195). It is generally accepted that interruption of this important pathway induces alterations in the circadian and cyclic rhythms, such as in the ovarian cycle. Studies conducted on rats show that blind animals with heavily degenerated photoreceptors, but with intact non-image forming light perception, have the ability to be synchronized to the light/dark cycle because they have an intact retinohypothalamic tract (196). The main retinorecipient area of the hypothalamus is the $\mathrm{SCN}$ which regulates biological rhythms (biological clock). The most characteristic neurotransmitter in this nucleus is VIP. Other important peptides in this area are: histidin isoleucin (PHI), gastrin-releasing peptide (GRP) and AVP. PACAP fibers, present in the retinohypothalamic tract, terminate in the SCN (67). PAC1 receptor mRNA was demonstrated in this region and there was a significant variation in PAC1 mRNA within the SCN and SON during both the light-dark cycle and constant darkness. The expression pattern was similar, but the expression level was higher during constant darkness. Peak levels were observed in the middle of both real and subjective days and nights $(197,198)$. Mice that are deficient in PAC1 receptors exhibit altered responsiveness of the biological clock to light-induced phase-shifts, but display robust circadian patterns of wheel-running behavior (199). In contrary, mice lacking the VPAC2 receptor, which responds to both PACAP and VIP, indicate that this receptor plays a crucial role in rhythm generation in the SCN. It was also shown that in PACl null mice the circadian expression of VIP mRNA in the SCN was altered (200).

It is probable that the effect of PACAP on KP neurons may be mediated by VIP and AVP neurons. Both VIP and AVP were found to activate about half of KP neurons located in the caudal ARC of female mice, but in males just about $10 \%$ of these cells (201). KP neurons in the rostral Pe of female mice receive vasopressinergic innervation from $\mathrm{SCN}$, which is thought to play a critical role in the mediation of the circadian signal to $\mathrm{GnRH}$ neurons for timing of the proestrous $\mathrm{GnRH}$ and consequent $\mathrm{LH}$ surge (202).

\section{RECENT POINT OF VIEW ON THE ROLE OF PACAP IN THE HYPOTHALAMO-HYPOPHYSIAL GONADOTROPIN SYSTEM}

Experimental data clearly show that PACAP38 is involved in the hypothalamo-hyphyseal gonadotropin regulation. As it was mentioned before, in the last two decades a new regulatory peptide was recognized. KP was discovered in 2001. During 


\section{Hypothesis of how PACAP may be involved in the regulation of $\mathrm{GnRH}$ functions}

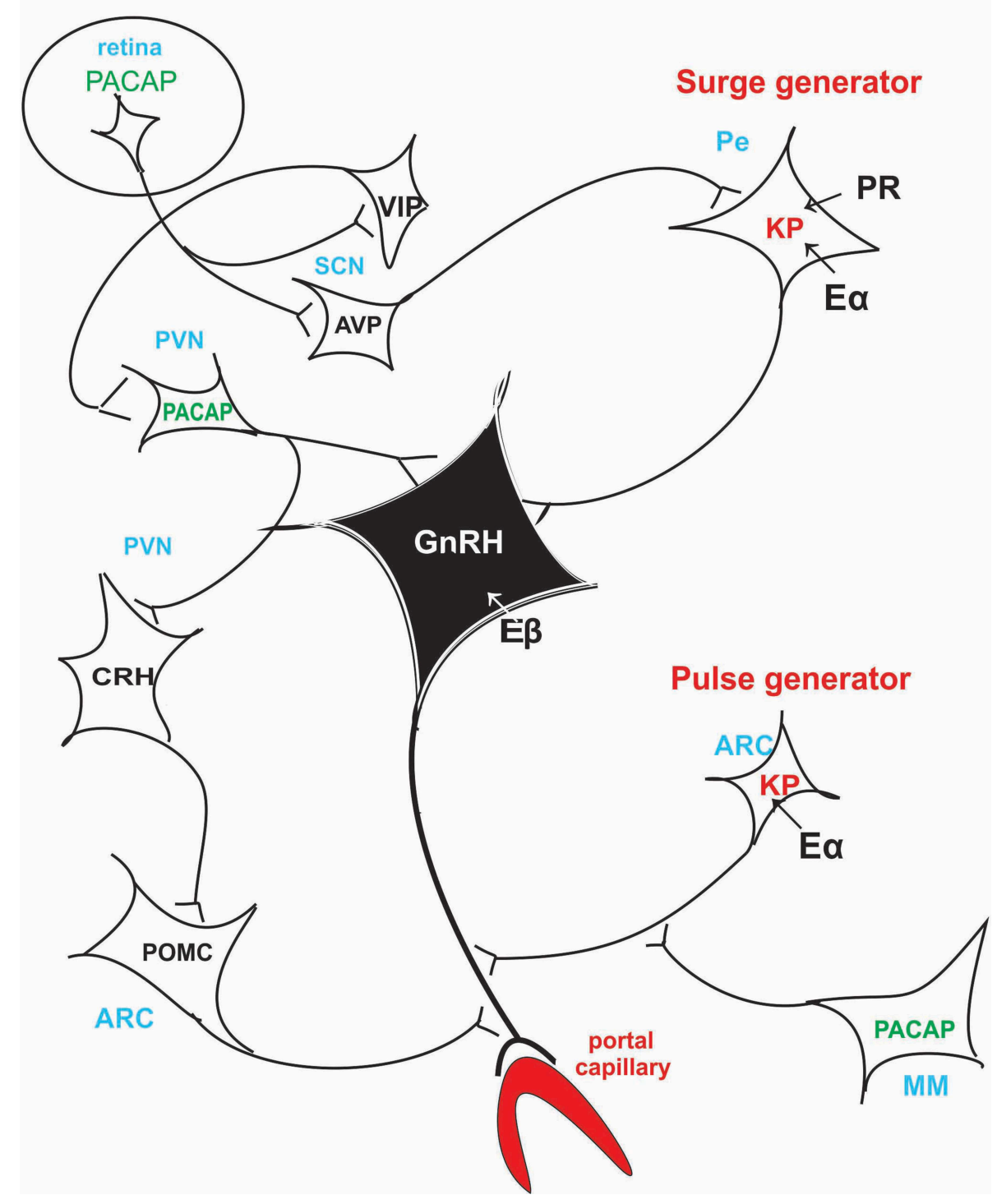

FIGURE 3 | Schematic illustration of the hypothetical pathway of how PACAP may be involved in the regulation of the GnRH release. Retinal PACAP may influence AVP and VIP cells located in the suprachiasmatic nucleus (biological clock). AVP fibers terminate on KP neurons which create the surge generator. PACAP neurons, located in PV, may receive information from the suprachiasmatic VIP neurons. PACAP may exert its effect directly on GnRH cell bodies or via CRH and POMC neurons on GnRH axons. PACAP neurons residing in MM may influence KP neurons which create the "pulse generator." ARC, arcuate nucleus; AVP, arginine vasopressin; $\mathrm{CRH}$, corticotropic hormone-releasing hormone; $\mathrm{E} \alpha$, estrogen receptor alpha; $\mathrm{E} \beta$, estrogen receptor beta; $\mathrm{GnRH}$, gonadotropic hormone-releasing hormone; KP, kisspeptin; MM, medial mammillary nucleus; PACAP, pituitary adenylate cyclase activating polypeptide; Pe, periventricular area; POMC, proopiomelanocortin; PR, progesterone receptor; PVN, paraventricular nucleus; SCN, suprachiasmatic nucleus; VIP, vasoactive intestinal polypeptide.

the last 18 years it became evident that this peptide plays a crucial role in stimulating GnRH. KP relays steroid hormone negative and positive feedback signals to $\mathrm{GnRH}$ neurons. It also stimulates the onset of puberty and relays photoperiodic information to GnRH neurons (203). In Kiss1 knockout male and female mice pulsatile LH secretion is suppressed, gonads are atrophic and puberty does not occur (204). It seems that $\mathrm{KP}$ plays an indispensable role as surge and pulse generator. Recent studies have demonstrated that iv administration of $\mathrm{KP}$ induces ovulation in heifers, where a mature follicle was maintained (205). KP administration, given as a slow constant $i v$ infusion of $\mathrm{Kp} 10$ (the shortest endogenous form of the 
KP molecules having biological activity), was also able to stimulate LH secretion and induced ovulation in anoestrus acyclic ewes (206).

PACAP knockout experiments suggest that PACAP is modulatory rather than mandatory in reproductive functions, and it has a fine tuning role in the regulation of gonadotropin hormone secretion. Its hypothalamic level decreases just before the critical period of proestrous stage (34) then GnRH starts to release into the portal blood. If we artificially enhance hypothalamic PACAP levels by icv administration (97), it inhibits the effect of KP and GnRH. Recent experiments show that in $\mathrm{L} \beta-\mathrm{T} 2$ cells there is an additive effect of KP and PACAP on gonadotropic hormone secretion (186). There is evidence that both KP and PACAP are released into the portal circulation $(41,207)$; however, it is not clear what the impact of this is. An in vivo experiment, when $\mathrm{KP}$ alone or $\mathrm{KP}$ and PACAP together administered $i c v$ to proestrus rats before the critical period, would help elucidate whether KP could induce ovulation when blocked by another agent for example by pentobarbital or PACAP. This experiment would give more insight into the role of these peptides. Figure 3 schematically illustrates the hypothetical pathway of how PACAP may influence GnRH release. PACAP, present in the retinal ganglion cells, may relay photic stimuli through AVP and KP neurons to the GnRH neuronal cell bodies residing in the septo-preoptico area. PACAP, present in the PVN, may receive information from suprachiasmatic VIP cells and may act directly on the septo-preoptico GnRH neuronal cell bodies or through $\mathrm{CRH}$ and POMC neurons on GnRH terminals. PACAP neurons located in MM region may influence $\mathrm{GnRH}$ release into the portal circulation via arcuate KP neurons.

Concerning the role of pituitary born PACAP, we only have data from in vitro experiments carried out by Kanasaki et al. $(123,124)$. Under physiological conditions "the locally produced pituitary PACAP and its receptor (PAC1) may be involved in the $\mathrm{GnRH}$ pulse frequency-dependent gonadotropin subunit gene expression". Pituitary born PACAP influences the responsiveness of gonadotropes to GnRH (119) in an autocrine and paracrine manner (116). The roles of PACAP on the hypothalamohypophysial gonadotropin system are as follows:

1. In physiological conditions PACAP in the hypothalamus of males is mainly stimulatory and in females it is inhibitory on gonadotropin hormone secretion.

2. PACAP delays puberty in both genders.

3. Pituitary-born PACAP is an auto- and paracrine factor. It is stimulatory in males. In females it is stimulatory on gonadotropin hormone secretion in the morning of proestrus, but inhibitory in the afternoon of proestrus.

\section{REFERENCES}

1. Miyata A, Arimura A, Dahl RR, Minamino N, Uehara A, Jiang L, et al. A Isolation of a novel 38 residue-hypothalamic polypeptide which stimulates adenylate cyclase in pituitary cells. Biochem Biophys Res Commun. (1989) 164:567-74. doi: 10.1016/0006-291X(89)91757-9
4. It seems that PACAP and PAC1 knockout leads to impared fertilization. This implies that PACAP is necessary for the full implantation of fertilized ova. In this sense PACAP and PAC1 knockout conditions are very similar to the effect of ER $\beta$ knockout on reproduction. PACAP knockout reduces mating and maternal behaviors as well.

\section{SIGNIFICANT GAPS IN RESEARCH}

Reviewing the data concerning the effect of PACAP on pituitary hormone release, it seems that the researchers mostly used pituitary cell cultures from male animals. It is clear that there is a sexual dimorphism in the responsiveness of pituitary cells to PACAP. This is the reason why it is difficult to draw a clear conclusion from the divergent data. The other difficulty is that in some experiments immortalized pituitary cells were used to study the effect of PACAP on hormone release and gene expression. These cell lines are removed from their natural environment and other factors are eliminated which are present in the pituitary in vivo.

There are many in vitro, but not enough in vivo experiments with PACAP38. Fournier et al. (208) summarized the modification of PACAP and the consequence of modifications for the binding properties and biological activity of the analogs. The main need is to produce stable, potent and selective agonists. However, the results also depend on the tissue used and the presence of PAC1 splice variants existing in the selected tissue. The use of PACAP in clinical treatment needs stable analogs because the half-life of the natural PACAP in the blood circulation is only $5-10 \mathrm{~min}$ (209) and only a very small amount, about $0.05 \%$ of the iv injected dose enters the central nervous system from the blood circulation $(210,211)$.

\section{AUTHOR CONTRIBUTIONS}

$\mathrm{KK}, \mathrm{AC}, \mathrm{ES}, \mathrm{OK}, \mathrm{AH}$, and FS have collected data in the literature in order to give timely and accurate review.

\section{FUNDING}

The work was supported by the Department of Anatomy, Histology and Embryology, Faculty of Medicine, Semmelweis University, Budapest, Hungary.

\section{ACKNOWLEDGMENTS}

For the memory of Dr. Akira Arimura who initiated and supported our PACAP research 30 years ago.

2. Miyata A, Jiang L, Dahl RD, Kitada C, Kubo K, Fujino M, et al. Isolation of a neuropeptide corresponding to the Nterminal 27 residues of the pituitary adenylate cyclase activating polypeptide with 38 residues (PACAP38). Biochem Biophys Res Commun. (1990) 170:643-8. doi: 10.1016/0006-291X(90) 92140-U 
3. Spengler D, Waeber C, Pantaloni C, Holsboer F, Bockaert J, Seeburg PH, et al. Differential signal transduction by five splice variants of the PACAP receptor. Nature. (1993) 365:170-5. doi: 10.1038/365170a0

4. Hosoya M, Kimura C, Ogi K, Ohkubo S, Miyamoto Y, Kugoh H, et al. Structure of the human pituitary adenylate cyclase activating polypeptide (PACAP) gene. Biochim Biophys Acta. (1992) 1129:199-206. doi: 10.1016/0167-4781(92)90488-L

5. Kimura C, Ohkubo S, Ogi K, Hosoya M, Ithoh Y, Onda H, et al. A novel peptide which stimulates adenylate cyclase: molecular cloning and characterization of the ovine and human cDNAs. BBRC. (1990) 166:81-9. doi: 10.1016/0006-291X(90)91914-E

6. Robberecht P, Gourlet P, De Neef P, Woussen-Colle MC, VandermeersPiret MC, Vandermeers A, et al. Structural requirements for the occupancy of pituitary adenylate-cyclase-activating-peptide (PACAP) receptors and adenylate cyclase activation in human neuroblastoma NB-OK-1 cell membranes. Discovery of PACAP(6-38) as a potent antagonist. Eur J Biochem. (1992) 207:239-46. doi: 10.1111/j.1432-1033.1992.tb17043.x

7. Sherwood NM, Krueckl SL, McRory JE. The origin and function of the pituitary adenylate cyclase-activating polypeptide (PACAP)/glucagon superfamily. Endocrinol Rev. (2000) 21:619-70. doi: 10.1210/edrv.21.6.0414

8. Adams BA, David Lescheid DW, Vickers ED, Crim LW, Sherwood NM. Pituitary adenylate cyclase-activating polypeptide and growth hormonereleasing hormone-like peptide in sturgeon, whitefish, grayling, flounder and halibut: cDNA sequence, exon skipping and evolution. Reg Pep. (2002) 109:27-37. doi: 10.1016/S0167-0115(02)00167-2

9. Jakab B, Reglodi D, Józsa R, Hollósy T, Tamás A, Lubics A, et al. Distribution of PACAP-38 in the central nervous system of various species determined by a novel radioimmunoassay. J Biochem Biophys Methods. (2004) 61:189-98. doi: 10.1016/j.jbbm.2004.03.002

10. Matsuda K, Nagano Y, Uchiyama M, Onoue S, Takahashi A, Kawauchi $\mathrm{H}$, et al. Pituitary adenylate cyclase-activating polypeptide (PACAP)like immunoreactivity in the brain of a teleost, Uranoscopus japonicus: immunohistochemical relationship between PACAP and adenohypophysial hormones. Regul Pept. (2005) 126:129-36. doi: 10.1016/j.regpep.2004.08.019

11. Nakamachi T, Kamata E, Tanigawa A, Konno N, Shioda S, Matsuda K. Distribution of pituitary adenylate cyclase-activating polypeptide 2 in zebrafish brain. Peptides. (2018) 103:40-7. doi: 10.1016/j.peptides.2018.03.006

12. Yon L, Feuilloley M, Chartrel N, Arimura A, Conlon JM, Fournier A, et al. Immunohistochemical distribution and biological activity of pituitary adenylate cyclase-activating polypeptide (PACAP) in the central nervous system of the frog Rana ridibunda. J Comp Neurol. (1992) 324:485-9. doi: $10.1002 /$ cne. 903240403

13. Yon L, Jeandel L, Chartrel N, Feuilloley M, Conlon JM, Arimura A, et al. Neuroanatomical and physiological evidence for the involvement of pituitary adenylate cyclase-activating polypeptide in the regulation of the distal lobe of the frog pituitary. J Neuroendocrinol. (1993) 5:289-96. doi: 10.1111/j.1365-2826.1993.tb00485.x

14. Yon L, Alexandre D, Montéro M, Chartrel N, Jeandel L, Vallarino M, et al. Pituitary adenylate cyclase-activating polypeptide and its receptors in amphibians. Microsc Res Tech. (2001) 54:137-57. doi: 10.1002/jemt.1129

15. Hu Z, Lelievre V, Tam J, Cheng JW, Fuenzalida G, Zhou X, et al. Molecular cloning of growth hormone-releasing hormone/pituitary adenylyl cyclaseactivating polypeptide in the frog Xenopus laevis: brain distribution and regulation after castration. Endocrinology. (2000) 141:3366-76. doi: 10.1210/endo.141.9.7663

16. Hu Z, Lelievre V, Rodriguez WI, Cheng JW, Waschek JA. Comparative distributions of pituitary adenylyl cyclase-activating polypeptide and its selective type I receptor mRNA in the frog (Xenopus laevis) brain. Regul Pept. (2002) 109:15-26. doi: 10.1016/S0167-0115(02)00166-0

17. Matsuda K, Kawaura H, Onoue S, Kashimoto K, Uchiyama M, Mochizuki $\mathrm{T}$, et al. Regional concentration and chromatographic characterization of pituitary adenylate cyclase-activating polypeptide (PACAP) in the brain of the bullfrog, Rana catesbeiana. Zoolog Sci. (2003) 20:1003-9. doi: $10.2108 /$ zsj.20.1003

18. Józsa R, Somogyvári-Vigh A, Reglödi D, Hollósy T, Arimura A. Distribution and daily variations of PACAP in the chicken brain. Peptides. (2001) 22:13717. doi: $10.1016 / \mathrm{S} 0196-9781(01) 00477-6$
19. Nowak JZ, Zawilska JB. PACAP in avians: origin, occurrence, and receptorspharmacological and functional considerations. Curr Pharm Des. (2003) 9:467-81. doi: 10.2174/1381612033391586

20. Chartrel N, Tonon MC, Vaudry H, Conlon JM. Primary structure of frog pituitary adenylate cyclase-activating polypeptide (PACAP) and effects of ovine PACAP on frog pituitary. Endocrinology. (1991) 129:3367-71. doi: 10.1210/endo-129-6-3367

21. Vaudry D, Gonzalez BJ, Basille M, Yon L, Fournier A, Vaudry H. Pituitary adenylate cyclase-activating polypeptide and its receptors: from structure to functions. Pharmacol Rev. (2000) 52:269-324.

22. Vaudry D, Falluel-Morel A, Bourgault S, Basille M, Burel D, Wurtz $\mathrm{O}$, et al. Pituitary adenylate cyclase-activating polypeptide and its receptors: 20 years after the discovery. Pharmacol Rev. (2009) 61:283-357. doi: 10.1124/pr.109.001370

23. Oride A, Kanasaki H, Kyo S. Role of pituitary adenylate cyclase-activating polypeptide in modulating hypothalamic-pituitary system. Reprod Med Biol. (2018) 17:234-41. doi: 10.1002/rmb2.12094

24. Dénes V, Geck P, Mester A, Gabriel R. Pituitary adenylate cyclase-activating polypeptide: 30 years in research spotlight and 600 million years in service. $J$ Clin Med. (2019) 8:E1488. doi: 10.3390/jcm8091488

25. Köves K, Arimura A, Vigh S, Somogyvári-Vigh A, Miller J. Immunohistochemical demonstration of a novel peptide, pituitary adenylate cyclase activating polypeptide, in the ovine hypothalamus. Endocrinology. (1990) 127:264-71. doi: 10.1210/endo-127-1-264

26. Köves K, Arimura A, Görcs TJ, Somogyvári-Vígh A. Comparative distribution of immunoreactive pituitary adenylate cyclase activating polypeptide and vasoactive intestinal polypeptide in rat forebrain. Neuroendocrinology. (1991) 54:159-69. doi: 10.1159/000125864

27. Vigh S, Arimura A, Köves K, Somogyvári-Vigh A, Sitton J, Fermin CD. Immunohistochemical localization of the neuropeptide, pituitary adenylate cyclase activating polypeptide (PACAP), in human and primate hypothalamus. Peptides. (1991) 12:313-8. doi: 10.1016/0196-9781(91)90018-K

28. Kivipelto L, Absood A, Arimura A, Sundler F, Håkanson R, Panula P. The distribution of pituitary adenylate cyclase-activating polypeptidelike immunoreactivity is distinct from helodermin and helospectin-like immunoreactivities in the rat brain. J Chem Neuroanat. (1992) 5:85-94. doi: 10.1016/0891-0618(92)90036-P

29. Tamada Y, Tanaka M, Ichitani Y, Okamura H, Yanaihara N, Ibata Y. Pituitary adenylate cyclase-activating polypeptide (PACAP)-like immunoreactive neuronal elements in rat hypothalamus and median eminence with special reference to morphological background of its effect on anterior pituitarylight and electron microscopic immunocytochemistry. Neurosci Lett. (1994) 180:105-8. doi: 10.1016/0304-3940(94)90498-7

30. Hannibal J. Pituitary adenylate cyclase-activating peptide in the rat central nervous system: an immunohistochemical and in situ hybridization study. $J$ Comp Neurol. (2002) 453:389-417. doi: 10.1002/cne.10418

31. Arimura A, Somogyvári-Vígh A, Miyata A, Mizuno K, Coy DH, Kitada C. Tissue distribution of PACAP as determined by RIA: highly abundant in the rat brain and testes. Endocrinology. (1991) 129:2787-9. doi: 10.1210/endo-129-5-2787

32. Masuo Y, Suzuki N, Matsumoto H, Tokito F, Matsumoto Y, Tsuda M, et al. Regional distribution of pituitary adenylate cyclase activating polypeptide (PACAP) in the rat central nervous system as determined by sandwich-enzyme immunoassay. Brain Res. (1993) 602:57-63. doi: 10.1016/0006-8993(93)90241-E

33. Hannibal J, Mikkelsen JD, Clausen H, Holst JJ, Wulff BS, Fahrenkrug J. Gene expression of pituitary adenylate cyclase activating polypeptide PACAP) in the rat hypothalamus. Regul Pept. (1995) 55:133-48. doi: 10.1016/0167-0115(94)00099-J

34. Moore JP Jr, Burger LL, Dalkin AC, Winters SJ. Pituitary adenylate cyclase activating polypeptide messenger RNA in the paraventricular nucleus and anterior pituitary during the rat estrous cycle. Biol Reprod. (2005) 73:491-9. doi: 10.1095/biolreprod.105.041624

35. Ogi K, Kimura C, Onda H, Arimura A, Fujino M. Molecular cloning and characterization of CDNA for the precursor of rat pituitary adenylate cyclase-activating polypeptide (PACAP). BBRC. (1990) 173:1271-9. doi: 10.1016/S0006-291X(05)80924-6 
36. Okazaki K, Itoh $\mathrm{Y}$, Ogi $\mathrm{K}$, Ohkubo S, Onda H. Characterization of murine PACAP mRNA. Peptides. (1995) 16:1295-9. doi: 10.1016/0196-9781(95)02018-R

37. Yamamoto K, Hashimoto H, Hagihara N, Nishino A, Fujita T, Matsuda $\mathrm{T}$, et al. Cloning and characterization of the mouse pituitary adenylate cyclase-activating polypeptide (PACAP) gene. Gene. (1998) 211:63-9. doi: 10.1016/S0378-1119(98)00110-3

38. Köves $\mathrm{K}$, Arimura A, Vigh S, Somogyvári-Vigh A, Miller J. Immunohistochemical localization of PACAP in the ovine digestive system. Peptides. (1993) 14:449-55. doi: 10.1016/0196-9781(93)90131-Y

39. Sundler F, Ekblad E, Absood A, Håkanson R, Köves K, Arimura A. Pituitary adenylate cyclase activating peptide: a novel vasoactive intestinal peptide-like neuropeptide in the gut. Neuroscience. (1992) 46:439-54. doi: 10.1016/0306-4522(92)90064-9

40. Köves K. Distribution of PACAP in mammalian nervous system. In: Reglodi D, Tamás A, editors. Current Topics In Neurotoxicity, Vol. 11. Pituitary Adenylate Cyclase Activating Polypeptide - PACAP. New York, NY: Springer Nature (2016). p. 161-78.

41. Dow RC, Bennie J, Fink G. Pituitary adenylate cyclase-activating peptide- 38 (PACAP)-38 is released into hypophysial portal blood in the normal male and female rat. J Endocrinol. (1994) 142:R1-4. doi: 10.1677/joe.0.142R001

42. Silverman AJ, Witkin JW, Silverman RC, Gibson MJ. Modulation of gonadotropin-releasing hormone neuronal activity as evidenced by uptake of fluorogold from the vasculature. Synapse. (1990) 6:154-60. doi: 10.1002/syn.890060206

43. Köves K, Vereczki V, Kausz M, Kántor O, Molnár J, Nemeskéri Á, et al. PACAP and VIP in the photoneuroendocrine system (PNES). Med Sci Mon. (2002) 8:SR5-20.

44. Condro MC, Matynia A, Foster NN, Ago Y, Rajbhandari AK, Van C, Jayaram B, et al. High-resolution characterization of a PACAP-EGFP transgenic mouse model for mapping PACAP-expressing neurons: PACAPEGFP transgenic mouse model. J Comp Neurol. (2016) 524:3827-48. doi: 10.1002/cne.24035

45. Dürr K, Norsted E, Gömüç B., Suarez E, Hannibal J, Meister B. Presence of pituitary adenylate cyclase-activating polypeptide (PACAP) defines a subpopulation of hypothalamic POMC neurons. Brain Res. (2007) 1186:20311. doi: 10.1016/j.brainres.2007.10.015

46. Köves K, Kántor O, Heinzlmann A, Lakatos A, Szabó E., Kirilly $\mathrm{E}$, et al. Advent and recent advance of the research on the role of pituitary adenylate cyclase activating polypeptide (PACAP) in the gonadotropic hormone secretion. J Mol Neurosci. (2014) 54:494-511. doi: 10.1007/s12031-014-0294-7

47. Vereczki V, Köves K, Tóth ZE, Baba A, Hashimoto H, Fógel K, et al. Pituitary adenylate cyclase-activating polypeptide does not colocalize with vasoactive intestinal polypeptide in the hypothalamic magnocellular nuclei and posterior pituitary of cats and rats. Endocrine. (2003) 22:225-37. doi: 10.1385/ENDO:22:3:225

48. Köves K, Görcs TJ, Arimura A. Colocalization of PACAP, but not of VIP, with oxytocin in the hypothalamic magnocellular neurons of colchicine treated and pituitary stalk sectioned rats. Endocrine. (1994) 2:1169-75.

49. Wuttke W, Benter S, Jarry H. Evidence for a steroid modulated expression of pituitary adenylate cyclase activating polypeptide (PACAP) in the anterior pituitary of rats. Neuroendocrinology. (1994) 60 (suppl. 1):17.

50. Köves K, Kántor O, Scammel JG, Arimura A. PACAP colocalizes with luteinizing and follicle-stimulating hormone immunoreactivities in the anterior lobe of the pituitary gland. Peptides. (1998) 19:1069-72. doi: 10.1016/S0196-9781(98)00049-7

51. Heinzlmann A, Kirilly E, Meltzer K, Szabó E., Baba A, Hashimoto H, et al. PACAP is transiently expressed in anterior pituitary gland of rats. In situ hybridization and cell immunoblot assay studies. Peptides. (2008) 29:571-7. doi: 10.1016/j.peptides.2007.12.009

52. Jin L, Tsumanuma I, Ruebel KH, Bayliss JM, Lloyd RV. Analysis of homogenous population of anterior pituitary folliculostellate cells by laser capture microdissection and reverse transcription polymerase chain reaction. Endocrinology. (2001) 142:1703-9. doi: 10.1210/endo.142. 5.8117

53. Gottschall PE, Tatsuno I, Miyata A, Arimura A. Characterization and distribution of binding sites for the hypothalamic peptide, pituitary adenylate cyclase-activating polypeptide. Endocrinology. (1990) 127:272-7. doi: 10.1210/endo-127-1-272

54. Gottschall PE, Tatsuno I, Arimura A. Hypothalamic binding sites for pituitary adenylate cyclase activating polypeptide: characterization and molecular identification. FASEB J. (1991) 5:194-9. doi: 10.1096/fasebj.5.2.1848519

55. Cauvin A, Buscail L, Gourlet P, De Neef P, Gossen D, Arimura A, et al. The novel VIP-like hypothalamic polypeptide PACAP interacts with high affinity receptors in the human neuroblastoma cell line NB-OK. Peptides. (1990) 11:773-7. doi: 10.1016/0196-9781(90)90194-A

56. Robberecht P, Gourlet P, Cauvin A, Buscail L, De Neef P, Arimura A, et al. PACAP and VIP receptors in rat liver membranes. Am J Physiol. (1991) 260:G97-102. doi: 10.1152/ajpgi.1991.260.1.G97

57. Harmar AJ, Arimura A, Gozes I, Journot L, Laburthe M, Pisegna JR, et al. International union of pharmacology. XVIII Nomenclature of receptors for vasoactive intestinal peptide and pituitary adenylate cyclase-activating polypeptide. Pharmacol Rev. (1998) 50:265-70.

58. Harmar AJ, Fahrenkrug J, Gozes I, Laburthe M, May V, Pisegna JR, et al. Pharmacology and functions of receptors for vasoactive intestinal peptide and pituitary adenylate cyclase-activating polypeptide: IUPHAR review $1 . \mathrm{Br}$ J Pharmacol. (2012) 166:4-17. doi: 10.1111/j.1476-5381.2012.01871.x

59. Bokaei PB, Ma XZ, Byczynski B, Keller J, Sakac D, Fahim S, et al. Identification and characterization of five-transmembrane isoforms of human vasoactive intestinal peptide and pituitary adenylate cyclase-activating polypeptide receptors. Genomics. (2006) 88:791-800. doi: 10.1016/j.ygeno.2006.07.008

60. Pisegna JR, Wank SA. Molecular cloning and functional expression of the pituitary adenylate cyclase-activating polypeptide type I receptor. Proc Natl Acad Sci USA. (1993) 90:6345-9. doi: 10.1073/pnas.90.13.6345

61. Dejda A, Bourgault S, Doan ND, Létourneau M, Couvineau A, Vaudry $\mathrm{H}$, et al. Identification by photoaffinity labeling of the extracellular $\mathrm{N}$-terminal domain of $\mathrm{PACl}$ receptor as the major binding site for PACAP. Biochimie. (2011) 93:669-77. doi: 10.1016/j.biochi.2010. 12.010

62. Shuto Y, Somogyvári-Vigh A, Onda H, Arimura A. Effect of hypophysectomy on pituitary adenylate cyclase activating polypeptide gene expression in the rat hypothalamus. Peptides. (1995) 16:407-13. doi: 10.1016/0196-9781(94)00198-F

63. Winters SJ, Dalkin AC, Tsujii T. Evidence that pituitary adenylate cyclase activating polypeptide suppresses follicle-stimulating hormone-messenger ribonucleic acid levels by stimulating follistatin gene transcription. Endocrinology. (1997) 138:4324-9. doi: 10.1210/endo.138.10.5441

64. Reglodi D, Gyarmati J, Ertl T, Borzsei R, Bodis J, Tamas A, et al. Alterations of pituitary adenylate cyclase-activating polypeptide-like immunoreactivity in the human plasma during pregnancy and after birth. J Endocrinol Invest. (2010) 33:443-45. doi: 10.1007/BF03346621

65. Csanaky K, Banki E, Szabadfi K, Reglodi D, Tarcai I, Czegledi L, et al. Changes in PACAP immunoreactivity in human milk and presence of PAC1 receptor in mammary gland during lactation. J Mol Neurosci. (2012) 48:631-7. doi: 10.1007/s12031-012-9779-4

66. Counis R, Laverrière JN, Garrel-Lazayres G, Cohen-Tannoudji J, Larivière S, Bleux C, et al. What is the role of PACAP in gonadotrope function? Peptides. (2007) 28:1797-804. doi: 10.1016/j.peptides.2007.05.011

67. Klein DC, Moore RY, Reppert SM. Suprachiasmatic Nucleus. The Mind's Clock. New York, NY; Oxford: Oxford University Press (1991).

68. Journot L, Waeber C, Pantaloni C, Holsboer F, Seeburg PH, Bockaert J, et al. Differential signal transduction by six splice variants of the pituitary adenylate cyclase-activating peptide (PACAP) receptor. Biochem Soc Trans. (1995) 23:133-7. doi: 10.1042/bst0230133

69. Blechman J, Levkowitz G. Alternative splicing of the pituitary adenylate cyclase-activating polypeptide receptor PAC1, mechanisms of fine tuning of brain activity. Front Endocrinol. (2013) 4:55. doi: 10.3389/fendo.2013.00055

70. Pantaloni C, Brabet P, Bilanges B, Dumuis A, Houssami S, Spengler D, et al. Alternative splicing in the $\mathrm{N}$-terminal extracellular domain of the pituitary adenylate cyclase-activating polypeptide (PACAP) receptor modulates receptor selectivity and relative potencies of PACAP-27 and PACAP-38 in phospholipase C activation. J Biol Chemistry. (1996) 271:22146-51. doi: $10.1074 / j b c .271 .36 .22146$ 
71. D’Agata V, Cavallaro S, Stivala F, Canonico PL. Tissue-specific and developmental expression of pituitary adenylate cyclase-activating polypeptide (PACAP) receptors in rat brain. Eur J Neurosci. (1996) 8:310-8. doi: 10.1111/j.1460-9568.1996.tb01215.x

72. Apostolakis EM, Riherd DN, O'Malley BW. PAC1 receptors mediate pituitary adenylate cyclase-activating polypeptide- and progesteronefacilitated receptivity in female rats. Mol Endocrinol. (2005) 19:2798-811. doi: 10.1210/me.2004-0387

73. Joo KM, Chung YH, Kim MK, Nam RH, Lee BL, Lee KH, et al. Distribution of vasoactive intestinal peptide and pituitary adenylate cyclase-activating polypeptide receptors (VPAC1, VPAC2, and PAC1 eceptor) in the rat brain. J Comp Neurol. (2004) 476:388-413. doi: 10.1002/cne.20231

74. Hashimoto $H$, Nogi $H$, Mori $K$, Ohishi $H$, Shigemoto $R$, Yamamoto $\mathrm{K}$, et al. Distribution of mRNA for a pituitary adenylate cyclase-activating polypeptide receptor in the rat brain: an in situ hybridization study. J Comp Neurol. (1996) 371:567-77. doi: 10.1002/(SICI)1096-9861(19960805)371:4<567::AID-CNE6>3.0.CO;2-2

75. Masuo Y, Ohtaki T, Masuda Y, Tsuda M, Fujino M. Binding sites for pituitary adenylate cyclase activating polypeptide (PACAP): comparison with vasoactive intestinal polypeptide (VIP) binding site localization in rat brain sections. Brain Res. (1992) 575:113-23. doi: 10.1016/0006-8993(92)90430-H

76. Resch JM, Boisvert JP, Hourigan AE, Mueller CR, Yi SS, Choi S. Stimulation of the hypothalamic ventromedial nuclei by pituitary adenylate cyclase activating polypeptide induces hypophagia and thermogenesis. Am J Physiol Regul Integr Comp Physiol. (2011) 301:R1625-34. doi: 10.1152/ajpregu.00334.2011

77. Nomura M, Ueta Y, Serino R, Kabashima N, Shibuya I, Yamashita H. PACAP type I receptor gene expression in the paraventricular and supraoptic nuclei of rats. Neuroreport. (1996) 8:67-70. doi: 10.1097/00001756-199612200-00014

78. Tatsuno I, Gottschall PE, Köves K, Arimura A. Demonstration of specific binding sites for pituitary adenylate cyclase activating polypeptide (PACAP) in rat astrocytes. Biochem Biophys Res Commun. (1990) 168:1027-33. doi: 10.1016/0006-291X(90)91132-C

79. Tatsuno I, Gottschall PE, Arimura A. Specific binding sites for pituitary adenylate cyclase activating polypeptide (PACAP) in rat cultured astrocytes: molecular identification and interaction with vasoactive intestinal peptide (VIP). Peptides. (1991) 12:617-21. doi: 10.1016/0196-9781(91)90110-B

80. Jaworski DM, Proctor MD. Developmental regulation of pituitary adenylatecyclase-activating polypeptide and $\mathrm{PAC}(1)$ receptor mRNA expression in the rat central nervous system. Brain Res Dev Brain Res. (2000) 120:27-39. doi: 10.1016/S0165-3806(99)00192-3

81. Ashur-Fabian O, Giladi E, Brenneman DE, Gozes I. Identification of VIP/PACAP receptors on rat astrocytes using antisense oligodeoxynucleotides. J Mol Neurosci. (1997) 9:211-22. doi: 10.1007/BF02800503

82. Grimaldi M, Cavallaro S. Functional and molecular diversity of PACAP/VIP receptors in cortical neurons and type I astrocytes. Eur J Neurosci. (1999) 11:2767-72. doi: 10.1046/j.1460-9568.1999.00693.x

83. Masmoudi O, Gandolfo P, Leprince J, Vaudry D, Fournier A, PatteMensah C, et al. Pituitary adenylate cyclase-activating polypeptide (PACAP) stimulates endozepine release from cultured rat astrocytes via a PKA-dependent mechanism. FASEB J. (2003) 17:17-27. doi: 10.1096/fj.02-0317com

84. Shioda S, Yada T, Nakajo S, Nakaya K, Nakai Y, Arimura A. Pituitary adenylate cyclase-activating polypeptide (PACAP): a novel A regulator of vasopressin-containing neurons. Brain Res. (1997) 765:81-90. doi: 10.1016/S0006-8993(97)00512-X

85. Mounien L, Bizet P, Boutelet I, Gourcerol G, Fournier A, Vaudry H, et al. Pituitary adenylate cyclase-activating polypeptide directly modulates the activity of proopiomelanocortin neurons in the rat arcuate nucleus. Neuroscience. (2006) 143:155-63. doi: 10.1016/j.neuroscience.2006.07.022

86. Mounien L, Bizet P, Boutelet I, Gourcerol G, Basille M, Gonzalez B, et al. Expression of PACAP receptor mRNAs by neuropeptide $\mathrm{Y}$ neurons in the rat arcuate nucleus. Ann NY Acad Sci. (2006) 1070:457-61. doi: 10.1196/annals.1317.061

87. Olcese J, McArdl CA, Middendorff R, Greenland K. Pituitary adenylate cyclase activating peptide and vasoactive intestinal peptide receptor expression in immortalized LHRH neurons. J Neuroendocrinol. (1997) 9:937-43. doi: 10.1046/j.1365-2826.1997.00663.x

88. Nakamachi T, Ohtaki H, Yofu S, Dohi K, Watanabe J, Hayashi D, et al. Pituitary adenylate cyclase activating polypeptide (PACAP) type 1 receptor $(\mathrm{PAC} 1 \mathrm{R})$ co-localizes with activity-dependent neuroprotective protein (ADNP) in the mouse brains. Regul Pept. (2008) 145:88-95. doi: 10.1016/j.regpep.2007.09.025

89. Shivers BD, Görcs TJ, Gottschall PE, Arimura A. Two high affinity binding sites for pituitary adenylate cyclase-activating polypeptide have different tissue distributions. Endocrinology. (1991) 128:3055-65. doi: 10.1210/endo-128-6-3055

90. Suda K, Smith DM, Ghatei MA, Murphy JK, Bloom SR. Investigation and characterization of receptors for pituitary adenylate cyclaseactivating polypeptide in human brain by radioligand binding and chemical cross-linking. J Clin Endocrinol Metab. (1991) 72:958-64. doi: 10.1210/jcem-72-5-958

91. Morrow JA, Lutz EM, West KM, Fink G, Harmar AJ. Molecular cloning and expression of a cDNA encoding a receptor or pituitary adenylate cyclase activating polypeptide (PACAP). FEBS Lett. (1993) 329:99-105. doi: 10.1016/0014-5793(93)80202-6

92. Vigh S, Arimura A, Gottschall PE, Kitada C, Somogyvári-Vigh A, Childs GV. Cytochemical characterization of anterior pituitary target cells for the neuropeptide, pituitary adenylate cyclase activating polypeptide (PACAP), using biotinylated ligands. Peptides. (1993) 14:59-65. doi: 10.1016/0196-9781(93)90011-5

93. Rawlings SR, Piuz I, Schlegel W, Bockaert J, Journot L. Differential expression of pituitary adenylate cyclase-activating polypeptide/vasoactive intestinal polypeptide receptor subtypes in clonal pituitary somatotrophs and gonadotrophs. Endocrinology. (1995) 136:2088-98. doi: 10.1210/endo.136.5.7720658

94. Hezareh M, Journot L, Bépoldin L, Schlegel W, Rawlings SR. PACAP/VIP receptor subtypes, signal transducers, and effectors in pituitary cells. Ann N Y Acad Sci. (1996) 805:315-27. doi: 10.1111/j.1749-6632.1996.tb17493.x

95. Rawlings SR, Hezareh M. Pituitary adenylate cyclase-activating polypeptide (PACAP) and PACAP/vasoactive intestinal polypeptide receptors: actions on the anterior pituitary gland. Endocr Rev. (1996) 17:2-29. doi: 10.1210/edrv-17-1-4

96. Köves K, Molnár J, Kántor O, Görcs T, Arimura A. New aspects of the neuroendocrine role of PACAP. Ann NYAcad Sci. (1996) 805:648-54. doi: 10.1111/j.1749-6632.1996.tb17535.x

97. Kántor O, Molnár J, Arimura A, Köves K. PACAP38 and PACAP27 administered intracerebroventricularly have an opposite effect on LH secretion. Peptides. (2000) 21:817-20. doi: 10.1016/S0196-9781(00)00214-X

98. Kántor O, Molnár J, Heinzlmann A, Arimura A, Fürst Z, Köves K. Study on the hypothalamic factors mediating the inhibitory effect of PACAP38 on ovulation. Peptides. (2001) 22:2163-8. doi: 10.1016/S0196-9781(01)00548-4

99. Heinzlmann A, Oláh Márk, Köves K. Intranasal application of PACAP and $\beta$-cyclodextrin before the "critical period of proestrous stage" can block ovulation. Biol Futura. (2019) 70:62-70. doi: 10.1556/019.70.2019.08

100. Sherwood NM, Adams BA, Isaac ER, Wu S, Fradinger EA. Knocked down and out: PACAP in development, reproduction and feeding. Peptides. (2007) 28:1680-7. doi: 10.1016/j.peptides.2007. 03.008

101. Isaac ER, Sherwood NM. Pituitary adenylate cyclase-activating polypeptide (PACAP) is important for embryo implantation in mice. Mol Cell Endocrinol. (2008) 280:13-9. doi: 10.1016/j.mce.2007.09.003

102. Sawangjaroen K, Curlewis JD. Effects of pituitary adenylate cyclaseactivating polypeptide (PACAP) and vasoactive intestinal polypeptide (VIP) on prolactin, luteinizing hormone and growth hormone secretion in the ewe. J Neuroendocrinol. (1994) 6:549-55. doi: 10.1111/j.1365-2826.1994.tb00618.x

103. Köves K, Kausz M, Fogel K, Arimura A. Presence of PACAP and in the retinohypothalamic pathway. Regul Pept. (1996) 64:98. doi: 10.1016/0167-0115(96)87915-8

104. MacLusky NJ, Naftolin F, Leranth C. Immunocytochemical evidence for direct synaptic connections between corticotrophin-releasing factor $(\mathrm{CRF})$ and gonadotrophin releasing hormone (GnRH)-containing neurons in the preoptic area of the rat. Brain Res. (1988) 439:391-35. doi: 10.1016/0006-8993(88)91501-6 
105. Almeida OF, Nikolarakis KE, Herz A. Evidence for the involvement of endogenous opioids in the inhibition of luteinizing hormone by corticotropin-releasing factor. Endocrinology. (1988) 122:1034-41. doi: 10.1210/endo-122-3-1034

106. Anderson ST, Sawangjaroen K, Curlewis JD. Pituitary adenylate cyclaseactivating polypeptide acts within the medial basal hypothalamus to inhibit prolactin and luteinizing hormone secretion. Endocrinology. (1996) 137:3424-9. doi: 10.1210/endo.137.8.8754770

107. Silverman AJ, Jhamandas J, Renaud LP. Localization of luteinizing hormonereleasing hormone (LHRH) neurons that project to the median eminence. $J$ Neuroscience. (1987) 7:2312-9.

108. Merchenthaler I, Görcs T, Sétáló G, Petrusz P, Flerkó B. Gonadotropinreleasing hormone $(\mathrm{GnRH})$ neurons and pathways in the rat brain. Cell Tiss Res. (1984) 237:15-29. doi: 10.1007/BF00229195

109. Silverman AJ, Livne I, Witkin JW. The gonadortophin-releasing hormone $(\mathrm{GnRH})$ neural systems: immunocytochemistry and in situ hybridization. In: Knobil E, editor. The Physiology of Reproduction. New York, NY: Raven Press (1994). p. 1683-709.

110. Banks WA, Uchida D, Arimura A, Somogyvári-Vigh A, Shioda S. Transport of pituitary adenylate cyclase-activating polypeptide across the blood-brain barrier and the prevention of ischemia induced death of hippocampal neurons. Ann N Y Acad Sci. (1996) 805, 270-7; discussion 277-9. doi: 10.1111/j.1749-6632.1996.tb17489.x

111. Nonaka N, Farr SA, Nakamachi T, Morley JE, Nakamura M, Shioda $\mathrm{S}$, et al. Intranasal administration of PACAP: uptake by brain and regional brain targeting with cyclodextrins. Peptides. (2012) 36:168-75. doi: 10.1016/j.peptides.2012.05.021

112. Szabó F, Horváth J, Heinzlmann A, Arimura A, Köves K. Neonatal PACAP administration in rats delays puberty through the influence of the LHRH neuronal system. Regul Pep. (2002) 109:49-55. doi: 10.1016/S0167-0115(02)00185-4

113. Daikoku S, Koide I, Chikamori-Aoyama M, Shimomura Y. Migration of LHRH neurons derived from the olfactory placode in rats. Arch Histol Cytol. (1993) 56:353-70. doi: 10.1679/aohc.56.353

114. Schwanzel-Fukuda M. Origin and migration of luteinizing hormonereleasing hormone neurons in mammals. Microsc Res Tech. (1999) 44:2-10. doi: 10.1002/(SICI)1097-0029(19990101)44:1<2::AID-JEMT2>3.0.CO;2-4

115. Choi EJ, Ha CM, Kim MS, Kang JH, Park SK, Choi WS, et al. Central administration of an antisense oligodeoxynucleotide against type I pituitary adenylate cyclase-activating polypeptide receptor suppresses synthetic activities of LHRH-LH axis during the pubertal process. Brain Res Mol Brain Res. (2000) 80:35-45. doi: 10.1016/S0169-328X(00) 00116-9

116. Radleff-Schlimme A, Leonhardt S, Wuttke W, Jarry H. Evidence for PACAP to be an autocrine factor on gonadotrope cells. Ann N Y Acad Sci. (1998) 865:486-91. doi: 10.1111/j.1749-6632.1998.tb11222.x

117. Szabó E, Nemeskéri Á, Heinzlmann A, Suzuki N, Arimura A, Köves K. Cell immunoblot assay study demonstrating the release of PACAP from individual anterior pituitary cells of rats and the effect of PACAP on LH release. Regul Pep. (2002) 109:75-81. doi: 10.1016/S0167-0115(02) 00186-6

118. Hulting AL, Lindgren JA, Hökfelt T, Eneroth P, Werner S, Patrono C, et al. Leukotriene $\mathrm{C} 4$ as a mediator of luteinizing hormone release from rat anterior pituitary cells. Proc Natl Acad Sci USA. (1985) 82:3834-8. doi: 10.1073/pnas.82.11.3834

119. Szabó E, Nemeskéri Á, Arimura A, Köves K. Effect of PACAP on LH release, studied by cell immunoblot assay, depends on the gender, on the time of day and in female rats on the day of estrous cycle. Regul Pep. (2004) 123:139-45. doi: 10.1016/j.regpep.2004.04.021

120. Culler MD, Paschall CS. Pituitary adenylate cyclase-activating polypeptide (PACAP) potentiates the gonadotropin-releasing activity of luteinizing hormone-releasing hormone. Endocrinology. (1991) 129:2260-2. doi: 10.1210/endo-129-4-2260

121. Hart GR, Gowing H, Burrin JM. Effects of a novel hypothalamic peptide pituitary adenylate cyclase-activating polypeptide, on pituitary hormone release in rats. J Endocrinol. (1992) 134:33-41. doi: 10.1677/joe.0.1340033

122. Kanasaki H, Mutiara S, Oride A, Purwana IN, Miyazaki K. Pulse frequencydependent gonadotropin gene expression by adenylate cyclase activating polypeptide 1 in perifused mouse pituitary gonadotroph L $\beta$ T2 cells. Biol Reprod. (2009) 81:465-72. doi: 10.1095/biolreprod.108.074765

123. Kanasaki H, Purwana IN, Oride A, Mijiddorj T, Sukhbaatar U, Miyazaki K. Circulating kisspeptin and pituitary adenylate cyclase activating polypeptide (PACAP) do not correlate with gonadotropin serum levels. Gynecol Endocrinol. (2013) 29:583-7. doi: 10.3109/09513590.2013.788624

124. Kanasaki H, Purwana IN, Miyazaki K. Possible role of PACAP and its PAC1 receptor in the differential regulation of pituitary LHbeta- and FSHbetasubunit gene expression by pulsatile GnRH. stimulation. Biol Repro. (2013) 88:1-5. doi: 10.1095/biolreprod.112.105601

125. Schomerus E, Poch A, Bunting R, Mason WT, McArdle CA. Effects of pituitary adenylate cyclase-activating polypeptide in the pituitary: activation of two signal transduction pathways in the gonadotrope-derived alpha T3-1 cell line. Endocrinology. (1994) 134:315-23. doi: 10.1210/endo.134.1.7903932

126. Tsujii T, Ishizaka K, Winters SJ. Effects of pituitary adenylate cyclaseactivating polypeptide on gonadotropin secretion and subunit messenger ribonucleic acids in perifused rat pituitary cells. Endocrinology. (1994) 135:826-33. doi: 10.1210/endo.135.3.7915230

127. Tsujii T, Winters SJ. Effects of pulsatile pituitary adenylate cyclase activating polypeptide (PACAP) on gonadotropin secretion and subunit mRNA levels in perifused rat pituitary cells. Life Sci. (1995) 56:1103-11. doi: 10.1016/0024-3205(95)00047-A

128. Tsujii T, Attardi B, Winters SJ. Regulation of alpha-subunit mRNA transcripts by pituitary adenylate cyclase-activating polypeptide (PACAP) in pituitary cell cultures and alpha T3-1 cells. Mol Cell Endocrinol. (1995) 113:123-30. doi: 10.1016/0303-7207(95)03613-C

129. Fujii Y, Okada Y, Moore JP Jr, Dalkin AC, Winters SJ. Evidence that PACAP and GnRH down-regulate follicle-stimulating hormone- $\beta$ mRNA levels by stimulating follistatin gene expression: effects on folliculostellate cells, gonadotrophs and L $\beta$ T2 gonadotroph cells. Mol Cell Endocrinol. (2002) 192:55-64. doi: 10.1016/S0303-7207(02)00109-0

130. Winters SJ, Moore JP Jr. PACAP an autocrine/paracrine regulator of gonadotrophs. Biol Reprod. (2011) 84:844-50. doi: 10.1095/biolreprod.110.087593

131. Köves K, Molnár J, Kántor O, Lakatos A, Görcs TJ, Somogyvári-Vigh A, et al. PACAP and participates in the regulation of the hormonal events preceding the ovulation. Acta Biol Hung. (1996) 47:239-49.

132. Grinevich V, Fournier A, Pelletier G. Effects of pituitary adenylate cyclaseactivating polypeptide (PACAP) on corticotropin-releasing hormone $(\mathrm{CRH})$ gene expression in the rat hypothalamic paraventricular nucleus. Brain Res. (1997) 773:190-6. doi: 10.1016/S0006-8993(97)01011-1

133. Jamen F, Rodriguez-Henche N, Pralong F, Jegou B, Gaillard R, Bockaert J, et al. PAC1 null females display decreased fertility. Ann N Y Acad Sci. (2000) 921:400-4. doi: 10.1111/j.1749-6632.2000.tb07004.x

134. Gray SR, Cummings KJ, Jirik FR, Sherwood NM. Targeted disruption of the pituitary adenylate cyclase-activating polypeptide gene results in early postnatal death associated with dysfunction of lipid and carbohydrate metabolism. Mol Endocrinol. (2001) 15:1739-47. doi: $10.1210 /$ mend.15.10.0705

135. Shintani N, Mori W, Hashimoto H, Imai M, Tanaka K, Tomimoto S, et al. Defects in reproductive functions in PACAP-deficient female mice. Regul Pept. (2002) 109:45-8. doi: 10.1016/S0167-0115(02)00169-6

136. Freeman ME, Kanyicska B, Lerant A, Nagy GM. Prolactin: structure, function, and regulation of secretion. Physiol Rev. (2000) 80:1523-631. doi: 10.1152/physrev.2000.80.4.1523

137. Nagy GM, Vígh S, Arimura A. PACAP induces prolactin and growth hormone release in lactating rats separated from their pups. Endocrine J. (1993) 40:169-73.

138. Anderson ST, Curlewis JD. PACAP stimulates dopamine neuronal activity in the medial basal hypothalamus and inhibits prolactin. Brain Res. (1998) 790:343-6. doi: 10.1016/S0006-8993(98)00176-0

139. Tohei A, Ikeda M, Hokao R, Shinoda M. The different effects of i.c.v. injection of pituitary adenylate cyclase activating polypeptide (PACAP) on prolactin secretion in adult male and lactating rats. Exp Anim. (2009) 58:489-95. doi: 10.1538/expanim.58.489

140. Vertongen P, Velkeniers B, Hooghe-Peters E, Robberecht P. Differential alternative splicing of PACAP receptor in pituitary cell subpopulations. Mol Cell Endocrinol. (1995) 113:131-5. doi: 10.1016/0303-7207(95)03626-I 
141. Jarry H, Leonhardt S, Schmidt WE, Creutzfeldt W, Wuttke W. Contrasting effects of pituitary adenylate cyclase activating polypeptide (PACAP) on in vivo and in vitro prolactin and growth hormone release in male rats. Life Sci. (1992) 51:823-30. doi: 10.1016/0024-3205(92)90609-S

142. Benter S, Leonhardt S, Wuttke W, Jarry H. Paracrine cell to cell interactions determine the effects of pituitary adenylate cyclase activating polypeptide (PACAP) on in vitro prolactin release from rat pituitary cells. Exp Clin Endocrinol Diabetes. (1995) 103:386-90. doi: 10.1055/s-0029-1211383

143. Propato-Mussafiri R, Kanse SM, Ghatei MA, Bloom SR. Pituitary adenylate cyclase-activating polypeptide releases 7B2, adrenocorticotrophin, growth hormone and prolactin from the mouse and rat clonal pituitary cell lines AtT-20 and GH3. J Endocrinol. (1992) 132:107-13. doi: $10.1677 /$ joe. 0.1320107

144. Ostrom KM. A review of the hormone prolactin during lactation. Prog Food Nutr Sci. (1990) 14:1-43.

145. Lacasse P, Ollier S, Lollivier V, Boutinaud M. New insights into the importance of prolactin in dairy ruminants. J Dairy Sci. (2016) 99:864-74. doi: 10.3168/jds.2015-10035

146. Czeglédi L, Tamas A, Borzsei R, Bagoly T, Kiss P, Horvath G, et al. Presence of pituitary adenylate cyclase-activating polypeptide (PACAP) in the plasma and milk of ruminant animals. Gen Comp Endocrinol. (2011) 172:115-9. doi: 10.1016/j.ygcen.2010.12.012

147. Skakkebaek M, Hannibal J, Fahrenkrug J. Pituitary adenylate cyclase activating polypeptide (PACAP) in the rat mammary gland. Cell Tissue Res. (1999) 298:153-9. doi: 10.1007/s004419900086

148. Tamás A, Vass RA, Helyes ZS, Csanaky K, Szanto Z, Nemeth J, et al. Exmination of PACAP During Lactation. In: Reglodi D, Tamás A, editors. Current Topics In Neurotoxicity, Vol. 11. Pituitary Adenylate Cyclase Activating Polypeptide - PACAP. New York, NY: Springer Nature (2016). p. 161-78.

149. Börzsei R, Mark L, Tamas A, Bagoly T, Bay C, Csanaky K, et al. Presence of pituitary adenylate cyclase activating polypeptide- 38 in human plasma and milk. Eur J Endocrinol. (2009) 160:561-5. doi: 10.1530/EJE-08-0911

150. Helyes Z, Pozsgai G, Börzsei R, Németh J, Bagoly T, Márk L, et al. Inhibitory effect of PACAP-38 on acute neurogenic and non-neurogenic inflammatory processes in the rat. Peptides. (2007) 28:1847-55. doi: 10.1016/j.peptides.2007.07.001

151. Steenstrup BR, Jørgensen JC, Alm P, Hannibal J, Junge J, Fahrenkrug J, et al. Pituitary adenylate cyclase activating polypeptide (PACAP): occurrence and vasodilatory effect in the human uteroplacental unit. Regul Pept. (1996) 61:197-204. doi: 10.1016/0167-0115(95)00156-5

152. Scaldaferri ML, Modesti A, Palumbo C, Ulisse S, Fabbri A, Piccione E, et al. Pituitary adenylate cyclase-activating polypeptide (PACAP) and PACAPreceptor type 1 expression in rat and human placenta. Endocrinology. (2000) 141:1158-67. doi: 10.1210/endo.141.3.7346

153. Koh PO, Won CK, Noh HS, Cho GJ, Choi WS. Expression of pituitary adenylate cyclase activating polypeptide and its type I receptor mRNAs in human placenta. J Vet Sci. (2005) 6:1-5. doi: 10.4142/jvs.2005.6.1.1

154. Oride A, Kanasaki H, Mijiddorj T, Sukhbaatar U, Yamada T, Kyo S. Expression and regulation of pituitary adenylate cyclase-activating polypeptide rat placental cells. Reprod Sci. (2016) 23:1080-106. doi: $10.1177 / 1933719116630421$

155. Horvath G, Nemeth J, Brubet R, Opper B, Koppan M, Tamás A, et al. Occurrence and functions of PACAP in the placenta. In: Reglodi D, Tamás, A, editors. Current Topics In Neurotoxicity, Vol. 11. Pituitary Adenylate Cyclase Activating Polypeptide - PACAP. New York, NY: Springer Nature (2016). p. 389-403.

156. Li S, Grinevich V, Fournier A, Pelletier G. Effects of pituitary adenylate cyclase-activating polypeptide (PACAP) on gonadotropin-releasing hormone and somatostatin gene expression in the rat brain. Brain Res Mol Brain Res. (1996) 41:157-62. doi: 10.1016/0169-328X(96)00086-1

157. Osuga $\mathrm{Y}$, Mitsuhashi N, Mizuno M. In vivo effect of pituitary adenylate cyclase activating polypeptide 38 (PACAP 38) on the secretion of luteinizing hormone (LH) in male rats. Endocrinol Jpn. (1992) 39:153-6. doi: 10.1507/endocri1954.39.153

158. Moore JP Jr, Wilson L, Dalkin AC, Winters SJ. Differential expression of the pituitary gonadotropin subunit genes during male rat sexual maturation: reciprocal relationship between hypothalamic pituitary adenylate cyclaseactivating polypeptide and follicle stimulating hormone expression. Biol Reprod. (2003) 69:234-41. doi: 10.1095/biolreprod.102.012757

159. Moore JP Jr, Villafuerte BC, Unick CA, Winters SJ. Developmental changes in pituitary adenylate cyclase activating polypeptide expression during the perinatal period: possible role in fetal gonadotroph regulation. Endocrinology. (2009) 150:4802-9. doi: 10.1210/en.2008-1649

160. Moore JP Jr, Yang RQ, Winters SJ. Targeted pituitary overexpression of pituitary adenylate-cyclase activating polypeptide alters postnatal sexual maturation in male mice. Endocrinology. (2012) 153:1421-34. doi: 10.1210/en.2011-1115

161. Larivière S, Garrel G, Robin MT, Counis R, Cohen-Tannoudji J. Differential mechanisms for PACAP and GnRH cAMP induction contribute to cross-talk between both hormones in the gonadotrope L $\beta$ T2 cell line. Ann N Y Acad Sci. (2006) 1070:376-39. doi: 10.1196/annals.13 17.048

162. Larivière S, Garrel-Lazayres G, Simon V, Shintani N, Baba A, Counis $\mathrm{R}$, et al. Gonadotropin-releasing hormone inhibits pituitary adenylyl cyclase activating polypeptide coupling to 3,'5'-cyclic adenosine-5'monophosphate pathway in L $\beta \mathrm{T} 2$ gonadotrope cells through novel protein kinase C isoforms and phosphorylation of pituitary adenylyl cyclaseactivating polypeptide type I receptor. Endocrinology. (2008) 149:6389-698. doi: 10.1210/en.2008-0504

163. Winters SJ, Moore JP. Paracrine control of gonadotrophs. Semin Reprod Med. (2007) 25:379-87. doi: 10.1055/s-2007-984744

164. Grafer CM, Thomas R, Lambrakos L, Montoya I, White S, Halvorson LM. GnRH stimulates expression of PACAP in the pituitary gonadotropes via both the PKA and PKC signaling systems. Mol Endocrinol. (2009) 23:102232. doi: 10.1210/me.2008-0477

165. Ortmann O, Asmus W, Diedrich K, Schulz KD, Emons G. Interactions of ovarian steroids with pituitary adenylate cyclase-activating polypeptide and GnRH in anterior pituitary cells. Eur J Endocrinol. (1999) 140:207-14. doi: $10.1530 /$ eje. 0.1400207

166. Zheng W, Grafer CM, Halvorson LM. Interaction of gonadal steroids and gonadotropin-releasing hormone on pituitary adenylate cyclaseactivating polypeptide (PACAP) and PACAP receptor expression in cultured rat anterior pituitary cells. Reprod Sci. (2014) 21:41-51. doi: 10.1177/1933719113488454

167. Grafer CM, Halvorson LM. Androgen receptor drives transcription of rat PACAP in gonadotrope cells. Mol Endocrinol. (2013) 27:1343-56. doi: $10.1210 / \mathrm{me} .2012-1378$

168. Ha CM, Kang JH, Choi EJ, Kim MS, Park J-W, Kim Y, et al. Progesterone increases mRNA levels of pituitary adenylate cyclase-activating polypeptide (PACAP) and type I PACAP receptor $\left(\mathrm{PAC}_{1}\right)$ in the rat hypothalamus. Mol Brain Res. (2000) 78:59-68. doi: 10.1016/S0169-328X(00) 00070-X

169. Németh J, Tamas A, Jozsa R, Horvath JE, Jakab B, Lengvari I, et al. Changes in PACAP levels in the central nervous system after ovariectomy and castration. Ann N Y Acad Sci. (2006) 1070:468-73. doi: 10.1196/annals.1317.063

170. Bloom FE, Battenberg ELF, Rivier J, Vale W. Corticotropin releasing factor (CRF) immunoreactive neurons and fibers in rat hypothalamus. Reg Peptides. (1982) 4:43-8. doi: 10.1016/0167-0115(82)90107-0

171. Dudás B, Merchenthaler I. Close juxtapositions between luteinizing hormone-releasing hormone-immunoreactive neurons and corticotropinreleasing factor-immunoreactive axons in the human diencephalon. J Clin Endocrinol Metab. (2002) 87:5778-84. doi: 10.1210/jc.2002-0 20996

172. Légrádi G, Hannibal J, Lechan RM. Pituitary adenylate cyclase-activating polypeptide-nerve terminals densely innervate corticotropin-releasing hormone-neurons in the hypothalamic paraventricular nucleus of the rat. Neurosci Lett. (1998) 246:145-8. doi: 10.1016/S0304-3940(98)00255-9

173. Goodman RL, Lehman MN, Smith JT, Coolen LM, de Oliveira CV, Jafarzadehshirazi MR, et al. Kisspeptin neurons in the arcuate nucleus of the ewe express both dynorphin A and neurokinin B. Endocrinology. (2007) 148:5752-60. doi: 10.1210/en.2007-0961

174. Skrapits K, Borsay BA, Herczeg L, Ciofi P, Liposits Z, Hrabovszky E. Neuropeptide co-expression in hypothalamic kisspeptin neurons 
of laboratory animals and the human. Front Neurosci. (2015) 9:29. doi: 10.3389/fnins.2015.00029

175. Moore AM, Coolen LM, Porter DT, Goodman RL, Lehman MN. KNDy cells revisited. Endocrinology. (2018) 159:3219-34. doi: 10.1210/en.201800389

176. Ramaswamy S, Guerriero KA, Gibbs RB, Plant TM. Structural interactions between kisspeptin and GnRH neurons in the mediobasal hypothalamus of the male rhesus monkey (Macaca mulatta) as revealed by double immunofluorescence and confocal microscopy. Endocrinology. (2008) 149:4387-95. doi: 10.1210/en.2008-0438

177. Smith JT, Popa SM, Clifton DK, Hoffman GE, Steiner RA. Kiss1 Neurons in the Forebrain as Central Processors for Generating the Preovulatory Luteinizing Hormone Surge. J Neurosci. (2006) 26:6687-94. doi: 10.1523/JNEUROSCI.1618-06.2006

178. Franceschini I, Lomet D, Cateau M, Delsol G, Tillet Y, Caraty A. Kisspeptin immunoreactive cells of the ovine preoptic area and arcuate nucleus co-express estrogen receptor alpha. Neurosci Lett. (2006) 401:225-30. doi: 10.1016/j.neulet.2006.03.039

179. Rance NE. Menopause and the human hypothalamus: evidence for the role of kisspeptin/neurokinin B neurons in the regulation of estrogen negative feedback. Peptides. (2009) 30:111-22. doi: 10.1016/j.peptides.2008. 05.016

180. Kuiper GG, Enmark E, Pelto-Huikko M, Nilsson S, Gustafsson JA. Cloning of a novel receptor expressed in rat prostate and ovary. Proc Natl Acad Sci USA. (1996) 93:5925-3. doi: 10.1073/pnas.93.12.5925

181. Hrabovszky E, Shughrue PJ, Merchenthaler I, Hajszan T, Carpenter CD, Liposits Z, et al. Detection of estrogen receptor-beta messenger ribonucleic acid and 125I- estrogen binding sites in luteinizing hormone-releasing hormone neurons of the rat brain. Endocrinology. (2000) 141:3506-9. doi: 10.1210/endo.141.9.7788

182. Hrabovszky E, Steinhauser A, Barabas K, Shughrue PJ, Petersen SL, Merchenthaler I, et al. Estrogen receptor-beta immunoreactivity in luteinizing hormone-releasing hormone neurons of the rat brain. Endocrinology. (2001) 142:3261-4. doi: 10.1210/endo.142. 7.8176

183. Hrabovszky E, Kallo I, Szlavik N, Keller E, Merchenthaler I, Liposits Z. Gonadotropin-releasing hormone neurons express estrogen receptor-beta. $J$ Clin Endocrinol Metab. (2007) 92:2827-30. doi: 10.1210/jc.2006-2819

184. de Roux N, Genin E, Carel JC, Matsuda F, Chaussain JL, Milgrom E. Hypogonadotropic hypogonadism due to loss of function of the KiSS1derived peptide receptor GPR54. Proc Natl Acad Sci USA. (2003) 100:109726. doi: $10.1073 /$ pnas. 1834399100

185. Stephens SBZ, Tolson KP, Rouse ML Jr, Poling MC, Hashimoto-Partyka MK, Mellon PL, et al. Absent Progesterone Signaling in Kisspeptin Neurons Disrupts the LH Surge and Impairs Fertility in Female Mice Endocrinology. (2015) 156:3091-7. doi: 10.1210/en.2015-1300

186. Mijiddorj T, Kanasaki H, Oride A, Hara T, Sukhbaatar U, Tumurbaatar $\mathrm{T}$, et al. Interaction between kisspeptin and adenylate cyclase-activating polypeptide 1 on the expression of pituitary gonadotropin subunits: a study using mouse pituitary L $\beta$ T2 cells. Biol Reprod. (2017) 96:1043-51. doi: 10.1093/biolre/iox030

187. Ross R, León S, Joseph C, Madara JC, Schafer D, Fergani C, et al. PACAP neurons in the ventral premammillary nucleus regulate reproductive function in the female mouse. Elife. (2018) 7:e35960. doi: 10.7554/eLife.35960

188. Tumurbaatar T, Kanasaki H, Oride A, Okada H, Hara T, Tumurgan $Z$, et al. Effect of pituitary adenylate cyclase-activating polypeptide (PACAP) in the regulation of hypothalamic kisspeptin expression. Gen Comp Endocrinol. (2019) 270:60-6. doi: 10.1016/j.ygcen.2018. 10.006

189. Scharrer E. Photo-neuro-endocrine systems: general concepts. Ann N Y Acad Sci. (1964) 117:13-22. doi: 10.1111/j.1749-6632.1964.tb 48155.x

190. Moore RY, Lenn NJ. A retinohypothalamic projection in the rat. J Comp Neurol. (1972) 146:1-14. doi: 10.1002/cne.901460102

191. Hendrickson AE, Wagoner N, Cowan WM. An autoradiographic and electron microscopic study of retino-hypothalamic connections. Z Zellforsch Mikrosk Anat. (1972) 135:1-26. doi: 10.1007/BF00307084
192. Provencio I, Rodriguez IR, Jiang G, Hayes WP, Moreira EF, Rollag MD A novel human opsin in the inner retina. J Neurosci. (2000) 20:600-5. doi: 10.1523/JNEUROSCI.20-02-00600.2000

193. Hannibal J, Ding JM, Chen D, Fahrenkrug J, Larsen PJ, Gillette MU, et al. Pituitary Adenylate Cyclase-Activating Peptide (PACAP) in the retinohypothalamic tract: a potential daytime regulator of the biological clock. J Neurosci. (1997) 7:2637-44. doi: 10.1523/JNEUROSCI.17-07-02637.1997

194. Hannibal J, Møller M, Ottersen OP, Fahrenkrug J. PACAP and glutamate are co-stored in the retinohypothalamic tract. J Comp Neurol. (2000) 418:14755. doi: 10.1002/(SICI)1096-9861(20000306)418:2<147::AID-CNE2> 3.0.CO;2-\#

195. Hannibal J, Fahrenkrug J. Neuronal input pathways to the brain's biological clock and their functional significance. Adv Anat Embryol Cell Biol. (2006) 182:1-71

196. Provencio I, Rollag MD, Castrucci AM. Photoreceptive net in the mammalian retina. This mesh of cells may explain how some blind mice can still tell day from night. Nature. (2002) 415:493. doi: 10.1038/ 415493a

197. Cagampang FR, Piggins HD, Sheward WJ, Harmar AJ, Coen CW. Circadian changes in PACAP type 1 (PAC1) receptor mRNA in the rat suprachiasmatic and supraoptic nuclei. Brain Res. (1998) 813:218-22. doi: 10.1016/S0006-8993(98)01044-0

198. Ajpru S, McArthur AJ, Piggins HD, Sugden D. Identification of PAC1 receptor isoform mRNAs by real-time PCR in rat suprachiasmatic nucleus. Brain Res Mol Brain Res. (2002) 105:29-37. doi: 10.1016/S0169-328X(02)00387-X

199. Harmar AJ. An essential role for peptidergic signalling in the control of circadian rhythms in the suprachiasmatic nuclei. J Neuroendocrinol. (2003) 15:335-8. doi: 10.1046/j.1365-2826.2003.01005.x

200. Georg B, Hannibal J, Fahrenkrug J. Lack of the PAC1 receptor alters the circadian expression of VIP mRNA in the suprachiasmatic nucleus of mice. Brain Res. (2007) 1135:52-7. doi: 10.1016/j.brainres.2006.12.001

201. Schafer D, Kane G, Colledge WH, Piet R, Herbison AE. Sex- and sub region-dependent modulation of arcuate kisspeptin neurons by vasopressin and vasoactive intestinal peptide. J Neuroendocrinol. (2018) 30:e12660. doi: $10.1111 /$ jne. 12660

202. Vida B, Deli L, Hrabovszky E, Kalamatianos T, Caraty A, Coen CW, et al. Evidence for suprachiasmatic vasopressin neurones innervating kisspeptin neurones in the rostral periventricular area of the mouse brain: regulation by oestrogen. J Neuroendocrinol. (2010) 22:1032-9. doi: 10.1111/j.1365-2826.2010.02045.x

203. Oakley AE, Clifton DK, Steiner RA. Kisspeptin signaling in the brain. Endocr Rev. (2009) 30:713-43. doi: 10.1210/er.2009-0005

204. Uenoyama Y, Nakamura S, Hayakawa Y, Ikegami K, Watanabe Y, Deura $\mathrm{C}$, et al. Lack of pulse and surge modes and glutamatergic stimulation of luteinising hormone release in Kiss1 knockout rats. J Neuroendocrinol. (2015) 27:187-97. doi: 10.1111/jne.12257

205. Leonardi CEP, Dias FCF, Adams GP, Araujo ER, Singh J. Kisspeptin induces ovulation in heifers under low plasma progesterone concentrations. Theriogenology. (2020) 141:26-34. doi: 10.1016/j.theriogenology.2019. 08.033

206. Caraty A, Lomet D, Sébert ME, Guillaume D, Beltramo M, Evans NP. Gonadotrophin-releasing hormone release into the hypophyseal portal blood of the ewe mirrors both pulsatile and continuous intravenous infusion of kisspeptin: an insight into kisspeptin's mechanism of action. $J$ Neuroendocrinol. (2013) 25:537-46. doi: 10.1111/jne.12030

207. Smith JT, Rao A, Pereira A, Caraty A, Millar RP, Clarke IJ. Kisspeptin is present in ovine hypophysial portal blood but does not increase during the preovulatory luteinizing hormone surge: evidence that gonadotropes are not direct targets of kisspeptin in vivo. Endocrinology. (2008) 149:1951-9. doi: 10.1210/en.2007-1425

208. Fournier A, Bourgault S, Chatenet D. The pharmacophoric determinants of PACAP. In: Reglodi D, Tamás A, editors. Current Topics In Neurotoxicity, Vol. 11. Pituitary Adenylate Cyclase Activating Polypeptide - PACAP. New York, NY: Springer Nature (2016). p. 111-32.

209. Li M, Maderdrut JL, Lertora JJ, Batuman V. Intravenous infusion of pituitary adenylate cyclase-activating polypeptide (PACAP) in a patient with multiple 
myeloma and myeloma kidney: a case study. Peptides. (2007) 28:1891-5. doi: 10.1016/j.peptides.2007.05.002

210. Banks WA, Kastin AJ, Komaki G, Arimura A. Passage of pituitary adenylate cyclase activating polypeptide1-27 and pituitary adenylate cyclase activating polypeptide1-38 across the blood-brain barrier. J Pharmacol Exp Ther. (1993) 267:690-6.

211. Uchida D, Arimura A, Somogyvári-Vigh A, Shioda S, Banks WA. Prevention of ischemia-induced death of hippocampal neurons by pituitary adenylate cyclase activating polypeptide. Brain Res. (1996) 736:280-6. doi: 10.1016/0006-8993(96) 00716-0
Conflict of Interest: The authors declare that the research was conducted in the absence of any commercial or financial relationships that could be construed as a potential conflict of interest.

Copyright @ 2020 Köves, Szabó, Kántor, Heinzlmann, Szabó and Csáki. This is an open-access article distributed under the terms of the Creative Commons Attribution License (CC BY). The use, distribution or reproduction in other forums is permitted, provided the original author(s) and the copyright owner(s) are credited and that the original publication in this journal is cited, in accordance with accepted academic practice. No use, distribution or reproduction is permitted which does not comply with these terms. 